\title{
In Vitro Pharmacological Characterization and In Vivo Validation of LSN3172176 a Novel M1 Selective Muscarinic Receptor Agonist Tracer Molecule for Positron Emission Tomographys
}

\author{
Adrian J. Mogg, Thomas Eessalu, Megan Johnson, Rebecca Wright, Helen E. Sanger, \\ Hongling Xiao, Michael G. Crabtree, Alex Smith, Ellen M. Colvin, Douglas Schober, \\ Donald Gehlert, Cynthia Jesudason, Paul J. Goldsmith, Michael P. Johnson, \\ Christian C. Felder, Vanessa N. Barth, and Lisa M. Broad \\ Eli Lilly \& Co. Ltd., Lilly Research Centre, Windlesham, Surrey, United Kingdom (A.J.M., H.E.S., M.G.C., A.S., E.M.C., P.J.G., L.M.B.) \\ and Eli Lilly \& Co. Ltd., Lilly Corporate Center, Indianapolis, Indiana (T.E., M.J., R.W., H.X., D.S., D.G., C.J., M.P.J., C.C.F., V.N.B.) \\ Received November 18, 2017; accepted April 5, 2018
}

\begin{abstract}
In the search for improved symptomatic treatment options for neurodegenerative and neuropsychiatric diseases, muscarinic acetylcholine M1 receptors (M1 mAChRs) have received significant attention. Drug development efforts have identified a number of novel ligands, some of which have advanced to the clinic. However, a significant issue for progressing these therapeutics is the lack of robust, translatable, and validated biomarkers. One valuable approach to assessing target engagement is to use positron emission tomography (PET) tracers. In this study we describe the pharmacological characterization of a selective M1 agonist amenable for in vivo tracer studies. We used a novel direct binding assay to identify nonradiolabeled ligands, including LSN3172176, with the favorable characteristics required for a PET tracer. In vitro functional and radioligand binding experiments revealed that LSN3172176 was a potent
\end{abstract}

partial agonist $\left(\mathrm{EC}_{50} 2.4-7.0 \mathrm{nM}, \mathrm{E}_{\max } 43 \%-73 \%\right)$, displaying binding selectivity for M1 mAChRs $\left(K_{d}=1.5 \mathrm{nM}\right)$ that was conserved across species (native tissue $K_{d}=1.02,2.66,8$, and 1.03 at mouse, rat, monkey, and human, respectively). Overall selectivity of LSN3172176 appeared to be a product of potency and stabilization of the high-affinity state of the M1 receptor, relative to other $m A C h R$ subtypes $(M 1>M 2, M 4$, M5 $>$ M3). In vivo, use of wild-type and mAChR knockout mice further supported the M1-preferring selectivity profile of LSN3172176 for the M1 receptor (78\% reduction in cortical occupancy in M1 KO mice). These findings support the development of LSN3172176 as a potential PET tracer for assessment of M1 mAChR target engagement in the clinic and to further elucidate the function of $\mathrm{M} 1 \mathrm{mAChRs}$ in health and disease.

\section{Introduction}

In the central nervous system, neurons that use the neurotransmitter acetylcholine (ACh) form the cholinergic system. The cortex and hippocampus are highly innervated by cholinergic projection neurons that originate in the nucleus basalis of Meynert complex. Cholinergic transmission in these forebrain regions modulates cellular excitability, synaptic plasticity, network function, and cognition (Hasselmo and Sarter, 2011; Teles-Grilo Ruivo and Mellor, 2013; Ballinger

The Oregon Alzheimer's Disease Center is supported by National Institutes of Health [Grant P30AG008017]. The authors are, or have been, employees of Eli Lilly and Company. Eli Lilly does not sell any of the compounds or devices mentioned in this article.

https://doi.org/10.1124/jpet.117.246454.

S This article has supplemental material available at jpet.aspetjournals.org et al., 2016). In Alzheimer disease (AD), in addition to the hallmarks of amyloid plaques, neurofibrillary tangles, and memory loss, there is a loss of cholinergic input to forebrain regions and reduced cholinergic transmission (Douchamps and Mathis, 2017). Acetylcholinesterase (AChE) inhibitors, the most broadly used treatments for $\mathrm{AD}$, inhibit the enzyme responsible for the breakdown of $\mathrm{ACh}$, acting to ameliorate the ACh deficit, thereby providing cognitive benefit (Tan et al., 2014). The extent of AChE inhibition has been shown to correlate to improvements in cognition (Rogers and Friedhoff, 1996; Bohnen et al., 2005); however, studies using $\left[{ }^{11} \mathrm{C}\right] \mathrm{PMP}$ $\mathrm{AChE}$ positron emission tomography (PET) to assess in vivo cortical AChE activity in subjects with $\mathrm{AD}$ report modest inhibition (22\%-27\%) at clinically used doses of the AchE inhibitor donepezil (Kuhl et al., 2000; Bohnen et al., 2005),

ABBREVIATIONS: ACh, acetylcholine; AChE, acetylcholinesterase; AD, Alzheimer disease; $\left[{ }^{11} \mathrm{C}\right] \mathrm{AF} 150(\mathrm{~S}), 1$-methylpiperidine-4-spiro-(2' methylthiazoline); CGRP, Calcitonin Gene-Related Peptide; GPCR, G protein-coupled receptor; GSK-1034702, 4-fluoro-6-methyl-1-(1-(tetrahydro-2Hpyran-4-yl)-4-piperidinyl)-1,3-dihydro-2H-benzimidazol-2-one; HPLC, high-performance liquid chromatography; ${ }^{123}$ I-IDEX, ${ }^{123}$ I-iododexetimide; KO, knockout; LC/MS, liquid chromatography-mass spectrometry; LSN3172176, ETHYL 4-(6-METHYL-2-OXO-2,3-DIHYDRO-1H-INDOL-1YL)-1,4'-BIPIPERIDINE-1'-CARBOXYLATE; mAChR, muscarinic acetylcholine receptor; $\left[{ }^{11} \mathrm{C}\right] \mathrm{NMPB},{ }^{11} \mathrm{C}-\mathrm{N}$-methyl piperidyl benzilate; $\left[{ }^{3} \mathrm{H}\right]$ NMS, ${ }^{3} \mathrm{H}-\mathrm{N}$-methylscopolamine; PEI, poly(iminoethylene); PET, positron emission tomography; $\left[{ }^{11} \mathrm{C}\right] \mathrm{PMP}, 1-\left[{ }^{11} \mathrm{C}\right] \mathrm{methylpiperidin}-4-\mathrm{yl}$ propionate; $\left[{ }^{11} \mathrm{C}\right] \mathrm{QNB},\left[{ }^{11} \mathrm{C}\right]$ quinuclidinyl benzilate. 
suggesting it should be possible to boost central cholinergic transmission further. Although a higher dose of donepezil (23 mg) has been developed and marketed (Cummings et al., 2013), it is associated with significant adverse events (donepezil prescribing information), hence other approaches to more selectively modulate the cholinergic system are of considerable interest as a way to improve the benefit-to-risk profile (Tan et al., 2014; Felder et al., 2018).

ACh mediates its effects through activation of two classes of $\mathrm{ACh}$ receptors, muscarinic $(\mathrm{mAChR})$ and nicotinic receptors. Clinical data clearly demonstrates mAChRs are important targets mediating procognitive effects of ACh. First, nonselective mAChR antagonists promote cognitive deficits in man (Rasmusson and Dudar, 1979; Robbins et al., 1997; Potter et al., 2000), whereas the direct-acting nonselective mAChR agonist xanomeline provided some evidence of cognitive benefit in patients with AD (Bodick et al., 1997; Veroff et al., 1998). mAChRs are G protein-coupled receptors and of the five isoforms identified (M1-5), M1 mAChRs are the most abundant in regions relevant for cognition (Levey et al., 1991; Wei et al., 1994; Flynn et al., 1995; Oki et al., 2005). Use of selective pharmacological tools and M1 knockout (KO) mice has revealed that M1 modulates neuronal signaling and excitability, synaptic transmission, and network function, and exerts procognitive effects (e.g., Anagnostaras et al., 2003; Shirey et al., 2009; Uslaner et al., 2013; Lange et al., 2015; Puri et al., 2015; Vardigan et al., 2015; Butcher et al., 2016; Dennis et al., 2016; Betterton et al., 2017). Importantly, M1 expression and function is conserved in postmortem human $\mathrm{AD}$ frontal cortex (Overk et al., 2010; Bradley et al., 2017).

One of the most significant issues with advancing a therapeutic for treatment of cognitive deficit in $\mathrm{AD}$ is the lack of robust, translatable, and validated biomarkers. The gold standard for assessing target engagement is to use PET tracers (Zhang and Villalobos, 2017); however, to date there has been no reported use of a PET tracer to guide clinical dosesetting for mAChR therapies, particularly for agonist ligands. Several companies have reported incorporation of pharmacodynamic biomarkers including reversal of scopolamine or nicotine abstinence-induced memory deficits or electroencephalography (EEG)-related measures (Nathan et al., 2013; https://www.heptares.com/news/261/74/Heptares-AnnouncesPositive-Results-from-Phase-1b-Clinical-Trial-with-HTL9936-aFirst-In-Class-Selective-Muscarinic-M1-Receptor-Agonistfor-Improving-Cognition-in-Dementia-and-Schizophrenia.html; Voss et al., 2016). Concurrent use of target engagement and pharmacodynamic biomarkers would enable a more thorough exploration of the optimal relationship between target engagement and relevant cognitive endpoints or pharmacodynamic measures.

Some PET and single-photon emission computed tomography (SPECT) tracers for muscarinic receptors have been reported; however, for the most part they are limited by low binding potentials, poor kinetic profiles, or a lack of selectivity, e.g., $\left[{ }^{11} \mathrm{C}\right]$ scopolamine, $\left[{ }^{11} \mathrm{C}\right] \mathrm{NMPB},\left[\mathrm{N}-{ }^{11} \mathrm{C}-\mathrm{methyl}\right]-$ benztropine, $\left[{ }^{11} \mathrm{C}\right] \mathrm{QNB}$ (Vora et al., 1983; Dewey et al., 1990; Varastet et al., 1992; Mulholland et al., 1995; Mcpherson, 2001; Zubieta et al., 2001). ${ }^{123}$ I-iododexetimide ( ${ }^{123} \mathrm{I}$-IDEX) has been used to image mAChRs in vivo with SPECT (Wilson et al., 1989; Müller-Gärtner et al., 1992; Boundy et al., 1995). In vitro, IDEX is a nonselective $\mathrm{mAChR}$ antagonist, but in vivo it measures, primarily, M1 receptor occupancy owing to the high expression of M1 mAChRs relative to other subtypes in the hippocampus and cortex. (Bakker et al., 2015). This in vivo selectivity in rodent brain probably reflects in part the high expression of $\mathrm{M} 1$ relative to other $\mathrm{mAChRs}$ in hippocampus and cortex (Oki et al., 2005), and this binding distribution is mirrored in clinical studies with ${ }^{123}$ I-IDEX (Wilson et al., 1989; Müller-Gärtner et al., 1992; Boundy et al., 1995). ${ }^{123} \mathrm{I}$ IDEX has been used to assess $\mathrm{mAChR}$ availability in olanzapine- and risperidone-treated subjects (Lavalaye et al., 2001) and for investigation of $\mathrm{mAChR}$ involvement in temporal lobe epilepsy (Mohamed et al., 2005). However, as IDEX and the aforementioned ligands are antagonists, they will bind to the total pool of mAChRs and will not distinguish between activated or uncoupled inactive receptors. Few G proteincoupled receptor (GPCR) agonist PET ligands are available, and while a nonselective $\mathrm{mAChR}$ agonist, xanomeline, and an M1 allosteric agonist, GSK-1034702, have both been carbonlabeled and evaluated clinically by PET, little specific CNS binding was observed with either ligand, despite clear brain penetration (Farde et al., 1996; Ridler et al., 2014). $\left[{ }^{11} \mathrm{C}\right]$ $\mathrm{AF} 150(\mathrm{~S})$ is another reported agonist PET ligand for M1 receptors that has been evaluated in rats (Buiter et al., 2013). AF150(S) is structurally related to cevimeline, a rigid analog of ACh. More recently, we have reported development of novel M1 agonist PET ligands (Jesudason et al., 2017; Nabulsi et al., 2017) that should greatly facilitate evaluation of direct target engagement and inform dose setting, ultimately providing a more definitive means of testing the M1 agonist hypothesis in the clinic. Herein, we report the detailed in vitro and ex vivo characterization of one of these ligands, LSN3172176.

\section{Methods and Materials}

LSN3172176 was prepared by Eli Lilly and Company (Lilly Research Centre, Windlesham, UK). [ $\left.{ }^{3} \mathrm{H}\right] \mathrm{LSN} 3172176$ (specific activity $1.295 \mathrm{TBq} / \mathrm{mmol}$ ) was synthesized by Quotient Bioscience, Cardiff, UK. For occupancy experiments, male Harlan Sprague-Dawley rats were purchased from Harlan (Indianapolis, IN, ranging from 200 to $300 \mathrm{~g}$ in weight). Male C57Bl6J mice were purchased from Taconic Biosciences (ranging from 15 to $34 \mathrm{~g}$ in weight; Germantown, NY). Muscarinic KO animals were also purchased from Taconic Biosciences: M1 (line\#1784), M2 (line\#1454), M3 (line\#1455), M4 (line\#1456), and M5 (line\#1457), weight range 15-47 g. All animals experiments were carried out in accordance with the Guide for the Care and Use of Laboratory Animals as adopted and promulgated by the U.S. National Institutes of Health, and were approved by the institution's Animal Care and Use Committee. ${ }^{3} \mathrm{H}-\mathrm{n}$ methylscopolamine $\left(\left[{ }^{3} \mathrm{H}\right] \mathrm{NMS}\right.$; specific activity $\left.3.16 \mathrm{TBq} / \mathrm{mmol}\right)$ and Chinese hamster ovary (CHO) cell membranes expressing human M1-M5 mAChR were obtained from PerkinElmer (Boston, MA).

\section{Nonradiolabeled Compound Direct Binding Experiments}

Filter Binding Conditions. For binding assays, recombinant human M1 membranes were incubated with compounds at $22^{\circ} \mathrm{C}$ for indicated times in $0.5 \mathrm{ml}$ assay volume of buffer composed of: $20 \mathrm{mM}$ HEPES, $100 \mathrm{mM} \mathrm{NaCl}$, and $10 \mathrm{mM} \mathrm{MgCl}_{2}, \mathrm{pH} \mathrm{7.5}$. Assays were stopped by filtration over glass fiber filters (Filtermat A, GF/C; PerkinElmer), which were previously soaked in $0.5 \%$ polyethylenimine (PEI), and washed by addition of cold Tris-buffer ( $50 \mathrm{mM}, \mathrm{pH} 7.4)$ using a Harvester 96 (Tomtec Life Sciences, Hamden, CT). Nonspecific binding was defined with $10 \mu \mathrm{M}$ atropine. Protein concentrations were determined using Coomasie Plus (Thermo Fisher Scientific, Waltham, MA) with bovine serum albumin as a standard. After filtration, the 
A

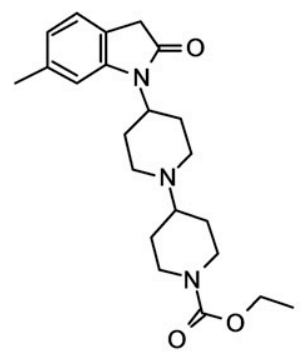

B

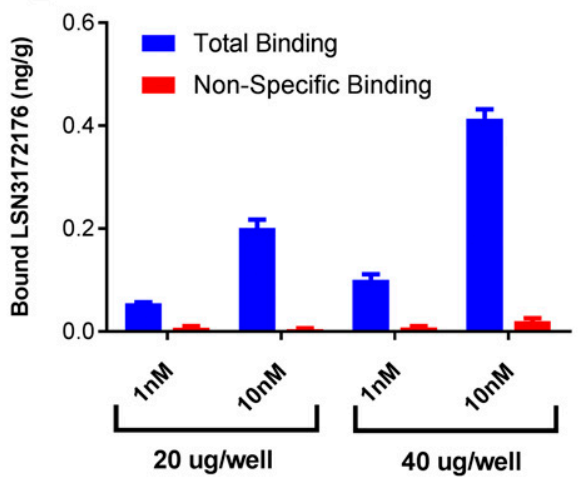

C

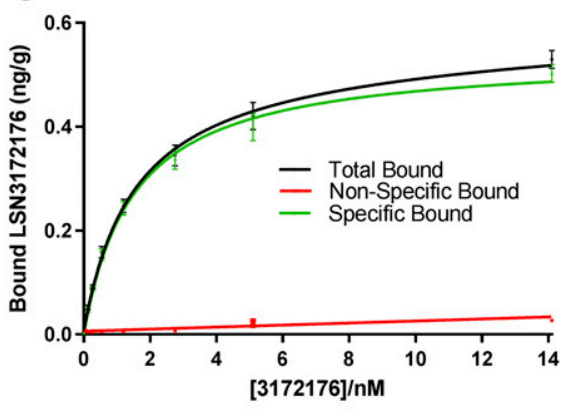

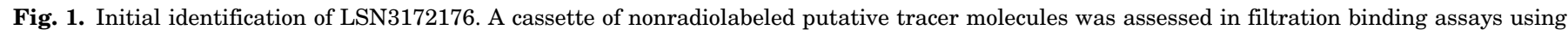

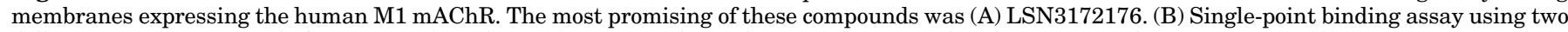

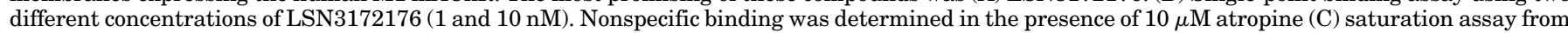

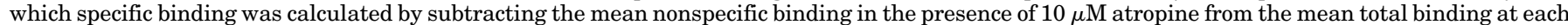

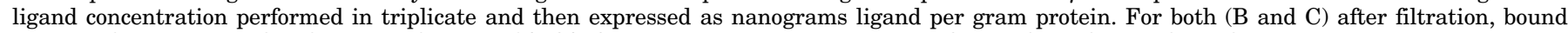
compound was extracted and measured using LC/MS/MS. Data points represent mean \pm S.E.M. from three independent experiments.

samples from each well area were excised from the Filtermat sheet, and the sections placed into $1.5 \mathrm{ml}$ Eppendorf tubes for processing for liquid chromatography-mass spectrometry (LC/MS) analysis.

Extraction and LC/MS Sample Prep. Each sample was incubated with $0.5 \mathrm{ml}$ of high-performance liquid chromatography (HPLC) grade methanol at room temperature for 30-60 minutes. To maximize sample extraction and solubilization each GF/C filter was homogenized with a probe-tip ultrasonic dismembrator (Fisher Scientific model 100; Pittsburgh, PA) at low-to-medium power setting until slurry of even consistency was obtained (10-20 seconds). Samples were clarified by centrifugation at $16,000 \mathrm{~g}$ for 20 minutes at room temp, then transferred to a glass HPLC sampler vial containing water to bring the final methanol content for all samples to $25 \%$. LC/MS/MS triple quadrupole mass spectrometer detection was carried out with a Shimadzu Prominence uHPLC system where 10- $\mu$ l samples were injected by autosampler onto a Zorbax SB-C18 column (Agilent Technologies, Wilmington, DE), $3.5 \mu \mathrm{m}, 2.1 \mathrm{~mm} \times$ $50 \mathrm{~mm}$, maintained at $30^{\circ} \mathrm{C}$. A universal 3-minute gradient elution profile was applied for all samples using a mobile phase composition ranging from $10 \%$ acetonitrile $+0.1 \%$ formic acid to $90 \%$ acetonitrile + $0.1 \%$ formic acid, $\mathrm{pH} 3$. The $\mathrm{LC}$ was coupled to an AB Sciex 5500 triple quadrupole mass spectrometer where the ligands were detected using multiple reaction monitoring methods that monitor the transition from precursor to product ion with mass-to-charge ratios $(\mathrm{m} / z)$ and elute from the column with a characteristic retention time. Samples were quantified by comparing area under the peak to a standard curve generated by extracting a series of target samples processed as described above to which known quantities of ligand ranging from 0.01 to $10 \mathrm{ng} / \mathrm{ml}$ were prepared in the appropriate matrix. Reported tracer levels are expressed in units of nanograms per milliliter of cell extract. GraphPad Prism (version 6.0; GraphPad Software Inc., La Jolla, CA) software was employed for calculations, curve fitting, and graphics. All points on graphs represent the mean \pm S.E.M. The number of samples per point is three to four.

\section{In Vitro Radioligand Binding Experiments}

Competition Binding. To investigate binding selectivity, the affinity of LSN3172176 was examined across mAChR subtypes M1-M5. All experiments were performed in assay buffer of the following composition: $20 \mathrm{mM}$ HEPES, $100 \mathrm{mM} \mathrm{NaCl}$, and $10 \mathrm{mM} \mathrm{MgCl}_{2}, \mathrm{pH}$ 7.5; and used $10 \mu \mathrm{g}$ of protein/well in a total assay volume of $1 \mathrm{ml}$ using deep well blocks. CHO cell membranes overexpressing human mAChR M1-M5 subtypes were incubated with a concentration of $\left[{ }^{3} \mathrm{H}\right] \mathrm{NMS}$ that was close to the calculated $\mathrm{K}_{\mathrm{d}}$ for each receptor (M1 $200 \mathrm{pM}, \mathrm{K}_{\mathrm{d}}=$ $196 \mathrm{pM}$; M2 $700 \mathrm{pM}, \mathrm{K}_{\mathrm{d}}=769 \mathrm{pM}$; M3 $700 \mathrm{pM}, \mathrm{K}_{\mathrm{d}}=642 \mathrm{pM}$; M4 $200 \mathrm{pM}, \mathrm{K}_{\mathrm{d}} 142 \mathrm{pM}$; M5 $400 \mathrm{pM}, \mathrm{K}_{\mathrm{d}}=410 \mathrm{pM}$ ), in the presence or absence of 11 different concentrations of compound. Nonspecific binding was determined in the presence of $10 \mu \mathrm{M}$ atropine. All assay incubations were initiated by the addition of membrane suspensions, and deep well blocks were shaken for 5 minutes to ensure complete mixing. Incubation was then carried out for 2 hours at $21^{\circ} \mathrm{C}$. Binding reactions were terminated by rapid filtration through GF/A filters (PerkinElmer) presoaked with $0.5 \% \mathrm{w} / \mathrm{v}$ PEI for 1 hour. Filters were then washed three times with $1 \mathrm{ml}$ ice-cold assay buffer. Dried filters were counted with Meltilex A scintillant using a Trilux 1450 scintillation counter (PerkinElmer). The specific bound counts (disintegrations per minute) were expressed as a percentage of the maximal binding observed in the absence of test compound (total) and nonspecific binding determined in the presence of $10 \mu \mathrm{M}$ atropine. Data analysis was accomplished using Excel and GraphPad Prism 7. The concentration-effect data were curve-fit using GraphPad Prism 7 to derive the potency $\left(\mathrm{IC}_{50}\right)$ of the test compound. The equilibrium inhibition constant $\left(\mathrm{K}_{\mathrm{i}}\right)$ of the test compound was then calculated by the Cheng-Prusoff equation: $\mathrm{K}_{\mathrm{i}}=\mathrm{IC}_{50}$ / $\left[1+\left([\mathrm{L}] / \mathrm{K}_{\mathrm{d}}\right)\right]$ (Cheng and Prusoff, 1973).

Saturation Binding. To further investigate selectivity, saturation experiments were performed using $\left[{ }^{3} \mathrm{H}\right] \mathrm{NMS}$ or $\left[{ }^{3} \mathrm{H}\right] \mathrm{LSN} 3172176$ across mAChR subtypes M1-M5. All experiments were performed in assay buffer of the following composition: $20 \mathrm{mM}$ HEPES, $100 \mathrm{mM}$

TABLE 1

Comparison of the in vitro signal-to-noise ratio of LSN3172176 binding to recombinant human M1 mAChRs vs. other known PET tracer ligands binding to their target receptors, also expressed in recombinant systems

\begin{tabular}{|c|c|c|c|c|c|}
\hline Target & Ligand & Membrane & [Ligand] & $\begin{array}{c}\text { In Vitro Signal-to-Noise } \\
\text { Ratio (S/N) }\end{array}$ & Human Tissue $B_{\max }$ \\
\hline & & $\mu g / w e l l$ & $/ n M$ & & $\mathrm{fmol} / \mathrm{mg}$ \\
\hline Human M1 & LSN3172176 & 20 & 10 & 21 & 224 (Table 4) \\
\hline Human $5-\mathrm{HT}_{2 \mathrm{~A}}$ & MDL100907 & 20 & 10 & 5 & $\begin{array}{l}136 \text { and } 164\left(\left[{ }^{3} \mathrm{H}\right] \text { ketanserin binding; }\right. \\
\text { Laruelle et al., 1993) }\end{array}$ \\
\hline Human CGRP & MK4232 & 20 & 10 & 7 & 33.4 (Hostetler et al., 2013) \\
\hline
\end{tabular}


A

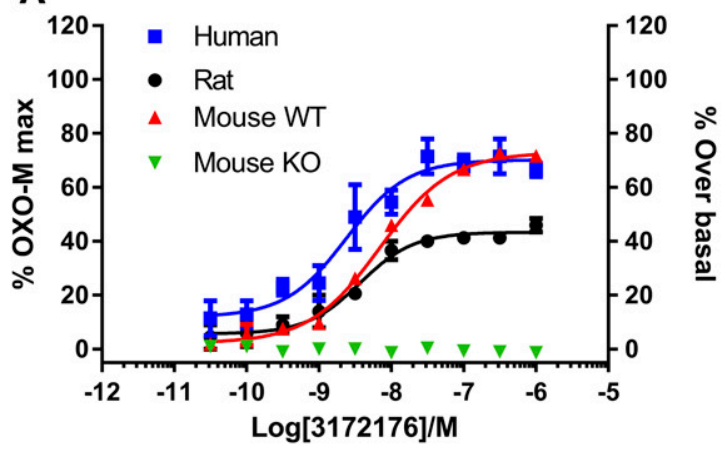

B

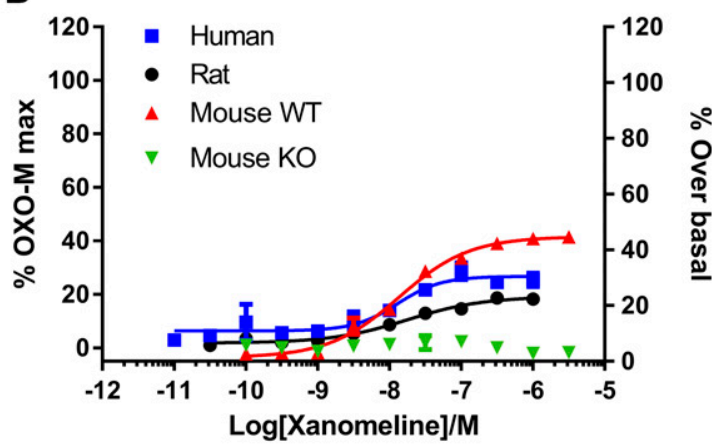

C

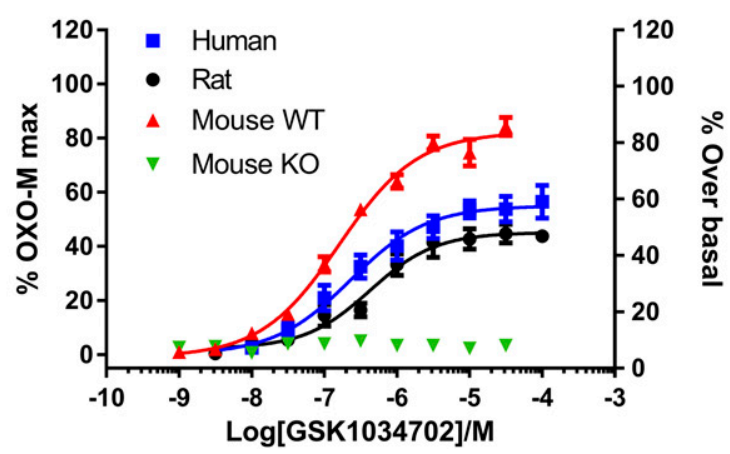

Fig. 2. In vitro functional profiling of LSN3172176 and comparators in native cortical tissues. Stimulation of GTP $\gamma\left[{ }^{35} \mathrm{~S}\right]$ binding to cortical membranes prepared from human, rat, mouse, or mice deficient in the M1 receptor, in response to increasing concentrations of (A) LSN3172176, (B) xanomeline, or (C) GSK1034702. Cortical membranes were incubated at $21^{\circ} \mathrm{C}$ for 30 minutes with compound. Data shown are increases in GTP $\gamma\left[{ }^{35} \mathrm{~S}\right]$ binding normalized to the response obtained with a maximally effective concentration of oxotremorine $\mathrm{M}$, or for mouse M1 KO tissue the increase in binding above buffer alone. Data points represent the mean \pm S.E.M. of three independent experiments each containing three to six replicates.

$\mathrm{NaCl}$ and $10 \mathrm{mM} \mathrm{MgCl} 2, \mathrm{pH} 7.5$; and used $20 \mu \mathrm{g}$ of protein or $10 \mu \mathrm{g}$ $\left(\left[{ }^{3} \mathrm{H}\right] \mathrm{NMS}\right) /$ well in a total assay volume of $1 \mathrm{ml}$ using deep well blocks. Nonspecific binding was determined in the presence of $10 \mu \mathrm{M}$ atropine. All assay incubations were initiated by the addition of membrane suspensions, and deep well blocks were shaken for 5 minutes to ensure complete mixing. Incubation was then carried out for 2 hours at $21^{\circ} \mathrm{C}$. Binding reactions were terminated by rapid filtration through GF/A filters (PerkinElmer) presoaked with $0.5 \% \mathrm{w} / \mathrm{v}$ PEI for 1 hour. Filters were then washed three times with $1 \mathrm{ml}$ ice-cold assay buffer. Dried filters were counted with Meltilex A scintillant using a Trilux 1450 scintillation counter (PerkinElmer). The specific bound counts (disintegrations per minute) were expressed as femtomole radioligand bound per milligram protein. Data analysis was accomplished using Excel and GraphPad Prism 7. The concentration-effect data were curve-fit using GraphPad Prism 7 to derive the $\mathrm{K}_{\mathrm{D}}$ and $\mathrm{B}_{\max }$.
Kinetic Binding. All experiments were performed in assay buffer of the following composition: $20 \mathrm{mM}$ HEPES, $100 \mathrm{mM} \mathrm{NaCl}$ and $10 \mathrm{mM} \mathrm{MgCl} 2, \mathrm{pH} \mathrm{7.5}$; and used $20 \mu \mathrm{g}$ of protein/well in a total assay volume of $1000 \mu \mathrm{l}$ using deep well blocks. Nonspecific binding was determined in the presence of $10 \mu \mathrm{M}$ atropine. For association experiments, buffer incubations were initiated at each time point by addition of membrane suspensions to buffer containing $2 \mathrm{nM}\left[{ }^{3} \mathrm{H}\right]$ LSN3172176 with nonspecific binding determined in the presence of $10 \mu \mathrm{M}$ atropine. For dissociation experiments, radioligand (same concentration as above) and membrane were incubated for 2 hours prior to addition of $10 \mu \mathrm{M}$ atropine at the indicated time points. Binding reactions were terminated by rapid filtration through GF/A filters (PerkinElmer) that were presoaked with $0.5 \% \mathrm{w} / \mathrm{v}$ PEI for 1 hour. Filters were then washed three times with $1 \mathrm{ml}$ ice-cold assay buffer. Dried filters were counted with Meltilex A scintillant using a Trilux 1450 scintillation counter (PerkinElmer). Data were fit to
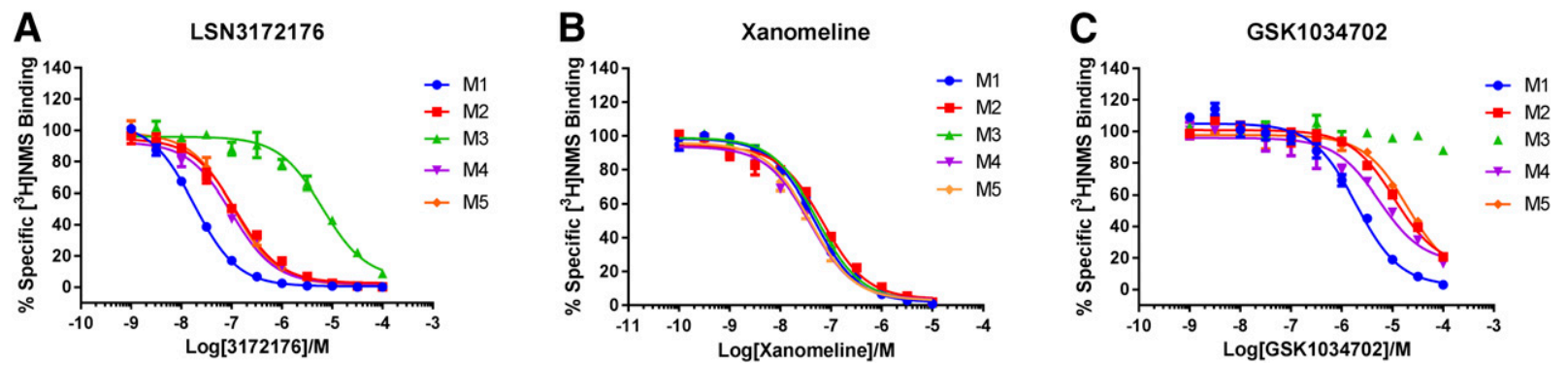

Fig. 3. Recombinant $m A C h R$ in vitro binding profile. Displacement of $\left[{ }^{3} \mathrm{H}\right] \mathrm{NMS}$ radioligand binding by increasing concentrations of (A) LSN3172176, (B) xanomeline, and (C) GSK1034702 across human recombinant mAChR subtypes M1-M5. Data points represent mean specific binding \pm S.E.M. from three independent experiments each containing three replicates. 
TABLE 2

Summary of in vitro $\mathrm{K}_{\mathrm{i}}$ values for displacement of ${ }^{3} \mathrm{H}-\mathrm{NMS}$ binding from human recombinant M1-M5 mAChRs

$\mathrm{K}_{\mathrm{i}}$ values for LSN3172176, xanomeline, and GSK1034702 were derived from IC $_{50}$ values, as described in Materials and Methods, from the data shown in Fig. 3. Values in parentheses indicate the fold-selectivity vs. the M1 mAChR.

\begin{tabular}{lrrrrr}
\hline \multirow{3}{*}{ Compound } & \multicolumn{5}{c}{ mAChR Subtype, Ki (nM) } \\
\cline { 2 - 6 } & \multicolumn{1}{c}{ M1 } & \multicolumn{1}{c}{ M2 } & \multicolumn{1}{c}{ M3 } & M4 & M5 \\
\hline LSN3172176 & 8.9 & $63.8(7.2)$ & $3031(341)$ & $41.4(4.7)$ & $55.6(6.2)$ \\
Xanomeline & 23.1 & $54.8(2.4)$ & $40.0(1.7)$ & $16.1(0.7)$ & $26.4(1.1)$ \\
GSK1034702 & 959.9 & $5674(5.9)$ & $61,570(64)$ & $2261(2.4)$ & $10,090(10.5)$ \\
\hline
\end{tabular}

association and dissociation curves to obtain kinetic parameters $\left(\mathrm{K}_{\mathrm{on}}\right.$, $\mathrm{K}_{\text {off }}, \mathrm{t}_{1 / 2}$ ).

Native Tissue GTP $\gamma\left[{ }^{35} \mathrm{~S}\right]$ Binding Assays. GTP $\gamma\left[{ }^{35} \mathrm{~S}\right]$ binding in human, rat, and mouse membranes was determined in triplicate using an antibody capture technique in 96-well plate format (DeLapp et al., 1999). Membrane aliquots (15 $\mu \mathrm{g} / \mathrm{well})$ were incubated with test compound and GTP $\gamma\left[{ }^{35} \mathrm{~S}\right](500 \mathrm{pM} /$ well) for 30 minutes. Labeled membranes were then solubilized with $0.27 \%$ Nonidet P-40 plus Gq $\alpha$ antibody (E17; Santa Cruz Biotechnology, Dallas, TX) at a final dilution of 1:200 and $1.25 \mathrm{mg} /$ well of anti-rabbit scintillation proximity beads. Plates were left to incubate for 3 hours and then centrifuged for 10 minutes at $2000 \mathrm{rpm}$. Plates were counted for 1 minute/well using a Wallac MicroBeta TriLux scintillation counter (PerkinElmer). All incubations took place at room temperature in GTP-binding assay buffer of the following composition: $20 \mathrm{mM}$ HEPES, $100 \mathrm{mM} \mathrm{NaCl}$, and $5 \mathrm{mM} \mathrm{MgCl}_{2}, \mathrm{pH}$ 7.5. Data were converted to percentage response compared with oxotremorine $\mathrm{M}(100 \mu \mathrm{M})$ or percentage over basal and $\mathrm{EC}_{50}$ values generated (four parameter-logistic curve) using GraphPad Prism 6.

$\left[{ }^{3}\right.$ H]LSN3172176 Autoradiography Assays. All experiments were performed in assay buffer of the following composition: $20 \mathrm{mM}$ HEPES, $100 \mathrm{mM} \mathrm{NaCl}, 10 \mathrm{mM} \mathrm{MgCl} 2$, $\mathrm{pH}$ 7.4. $\left[{ }^{3} \mathrm{H}\right] \mathrm{LSN} 3172176$ was used at a final concentration of $5 \mathrm{nM}$, with atropine $(10 \mu \mathrm{M})$ used to define nonspecific binding. Wild-type, $\mathrm{M} 1 \mathrm{KO}$, and M4 KO mice were received from Taconic Biosciences and sacrificed following a 1 week acclimation. Mice were decapitated and brains were removed, quick frozen in isopentane on dry ice, then stored at $-80^{\circ} \mathrm{C}$. On the day of sectioning, frozen tissue was mounted on cryostat chucks and equilibrated to cryostat temperature (chamber temperature $\sim-20^{\circ} \mathrm{C}$, object temperature $\left.\sim-16^{\circ} \mathrm{C}\right)$. Frozen sections $(20 \mu \mathrm{m})$ were cut and thaw-mounted on Fisher SuperFrost Plus 1 inch $\times 3$ inch slides. Sections were allowed to dry at room temperature, then stored frozen at $-80^{\circ} \mathrm{C}$ in sealed plastic. On the day of experiment, slide-mounted tissue sections were thawed to room temperature before removal from sealed containers, preincubated at room temperature in assay buffer for 15 minutes to remove endogenous receptor ligands, then dried completely under a stream of cool air. Sections were incubated for 120 minutes on ice in assay buffer containing radioligand with or without cold displacer for nonspecific binding. Following incubation, the sections were rinsed twice by immersing in approximately $3 \times$ volume of ice-cold assay buffer for 90 seconds, followed by a final rinse in ice-cold purified water, then dried under a stream of warm air. Slides were attached to paper with double-sided tape and placed in film cassettes. Fuji BAS-TR2025 phosphorimaging plates were exposed to tissue sections for empirically determined duration $(\sim 72$ hours). Radioactive standards calibrated with known amounts of $\left[{ }^{3} \mathrm{H}\right]$

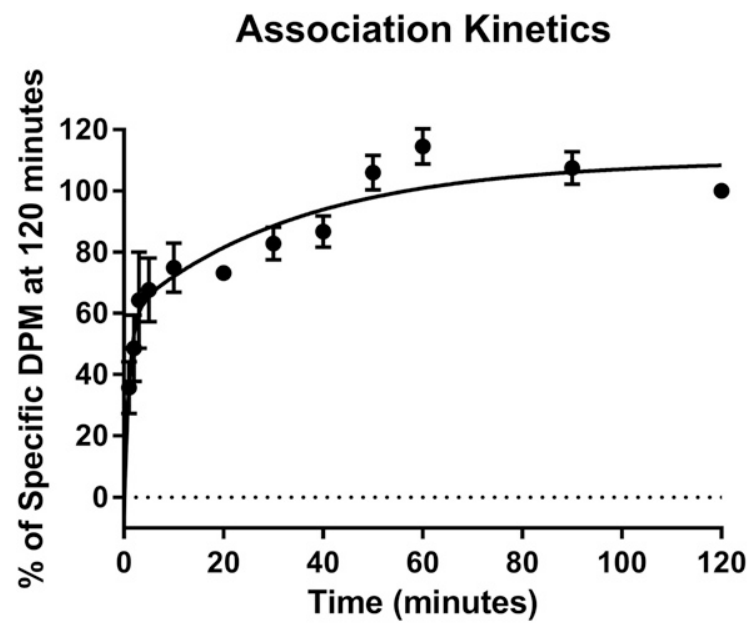

\section{Dissociation Kinetics}

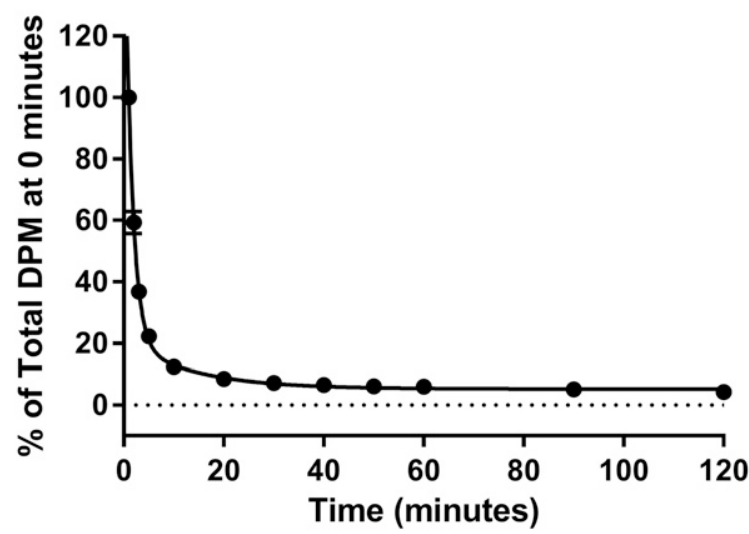

\begin{tabular}{|l|r|}
\hline KFast & $0.9655 \mathrm{~min}^{-1}$ \\
\hline KSlow & $0.02854 \mathrm{~min}^{-1}$ \\
\hline Fast HalfLife & $0.7179 \mathrm{~min}$ \\
\hline Slow HalfLife & $24.29 \mathrm{~min}$ \\
\hline
\end{tabular}

\begin{tabular}{|l|r|}
\hline KFast & $0.6968 \mathrm{~min}^{-1}$ \\
\hline KSlow & $0.07347 \mathrm{~min}^{-1}$ \\
\hline Fast HalfLife & $9.435 \mathrm{~min}$ \\
\hline Slow HalfLife & $0.9947 \mathrm{~min}$ \\
\hline
\end{tabular}

Fig. 4. $\left[{ }^{3} \mathrm{H}\right] \mathrm{LSN} 3172176$ association and dissociation kinetics. For association rate experiments (A) specific binding was calculated by subtracting the mean nonspecific binding in the presence of $10 \mu \mathrm{M}$ atropine from the mean total binding at each time point performed in quadruplicate. For dissociation rate experiments (B) binding was expressed as a percent of total bound DPM (disintegrations per minute) at 0 minutes. Data points represent mean \pm S.E.M. from three independent experiments each containing four replicates. 

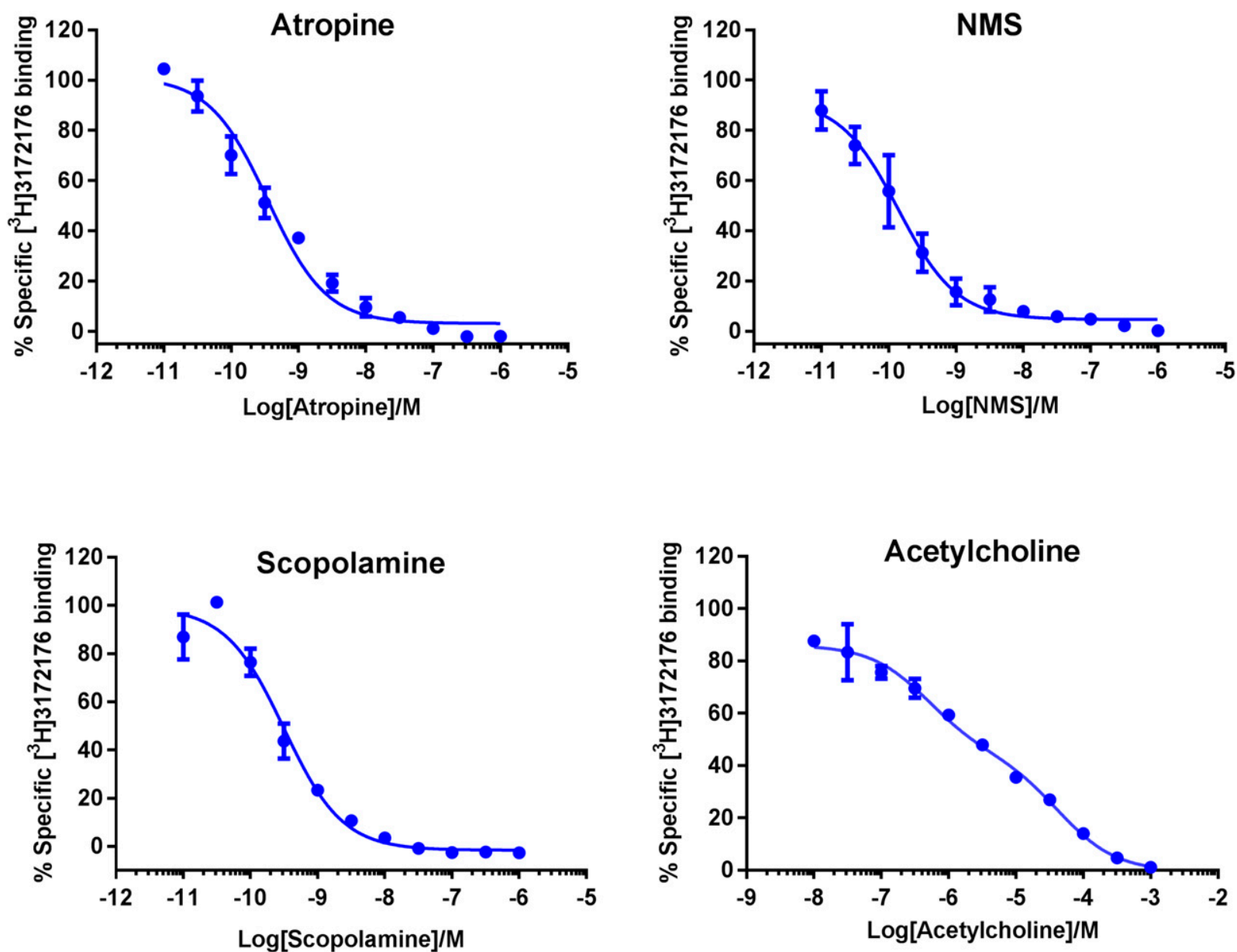

Fig. 5. Displacement of $\left[{ }^{3} \mathrm{H}\right] \mathrm{LSN} 3172176$ by known orthosteric mAChR ligands. $\left[{ }^{3} \mathrm{H}\right] \mathrm{LSN} 3172176$ radioligand binding (4 nM) at the human M1 recombinant $\mathrm{mAChR}$ was assessed in the presence of increasing concentrations of atropine, NMS, scopolamine, and acetylcholine. Data points represent mean specific binding \pm S.E.M. from three independent experiments each containing three replicates.

(ARC-0123; American Radiolabeled Chemicals, Inc., St. Louis, MO), were coexposed with each plate. Autoradiogram analysis was performed using a computer-assisted image analyzer (MCID Elite, 7.0; Imaging Research Inc., St. Catherines, ON). Images were colorized using the MCID software and stored as TIFF files.

Tracer Distribution in M1-M5 KO Mice by LC/MS/MS. LSN3172176 was formulated in 25\% $\beta$-cyclodextrin and a bolus intravenous injection of $10 \mu \mathrm{g} / \mathrm{kg}$ of LSN3172176 (dose volume of $0.5 \mathrm{ml} / \mathrm{kg}$ in rats and a dose volume of $5 \mathrm{ml} / \mathrm{kg}$ in mice) given into the lateral tail vein. Rodents were sacrificed by cervical dislocation 20 minutes following tracer administration. Cerebellum, frontal cortex, striatum, and plasma were collected from each animal. Tissues were dissected out, weighed, and placed in conical centrifuge tubes on ice. Four volumes (w/v) of acetonitrile containing $0.1 \%$ formic acid were added to each tube. Samples were then homogenized using an ultrasonic probe and centrifuged at $15,000 \mathrm{rpm}$ for 20 minutes. Supernatant liquid $(100 \mu \mathrm{l})$ was diluted by adding sterile water $(300 \mu \mathrm{l})$ in HPLC injection vials for subsequent LC/MS/MS analysis.

LSN3172176 concentrations were measured with a model Shimadzu SIL-20AC/HT HPLC autosampler (Shimadzu Corporation, Kyoto, Japan) linked to a Triple Quad 5500 mass spectrometer (AB SCIEX, Framingham, MA). An Agilent ZORBAX XDB-C18 column $(2.1 \mathrm{~mm} \times 50 \mathrm{~mm}$; $3.5 \mu \mathrm{M}$; part no. 971700-902) was used for the HPLC. The precursor-to-product ion transition monitored was $\mathrm{Q} 1=$ 386.146, Q3 = 128.000. A gradient method lasting 5 minutes that consisted of mobile phase of various ratios of water (A) and acetonitrile (B) with $0.1 \%$ formic acid. The initial conditions were $90 \% \mathrm{~A}$ and $10 \%$ $\mathrm{B}$, and the final conditions were $90 \% \mathrm{~A}, 10 \% \mathrm{~B}$. Standards were prepared by adding known quantities of analyte to samples of brain tissue and plasma from nontreated animals and processed as described above.

Levels of LSN3172176 measured in frontal cortex and striatum (rich in muscarinic receptor expression) were taken to represent total ligand binding in a tissue. Cerebellar levels were used to represent nonspecific binding. The difference between the ligand concentration measured in the total binding region, the frontal cortex, and striatum to that measured in cerebellum represents specific binding to muscarinic receptors. The binding potential (BP), or signal to noise is calculated by taking the ratio of tracer measured in the total binding tissue (frontal cortex, striatum) divided by those measured in the nonspecific tissue (cerebellum).

Rat M1 Occupancy of Scopolamine. The same procedures were also applied to evaluate the occupancy of scopolamine after intravenous injection in Harlan Sprague Dawley rats (ranging from 200 to $300 \mathrm{~g}$ in weight). The doses of scopolamine included 0.01, 0.03, 0.06, $0.1,0.3 \mathrm{mg} / \mathrm{kg}$ and were administered 30 minutes prior to the tracer injection. A similar analytical protocol was used to determine the concentration of LSN3172176. Occupancy was calculated as previously described above.

\section{Results}

Selection of LSN3172176 as a Putative Tracer Molecule. Putative tracer molecules and compounds were screened at a single concentration of $10 \mathrm{nM}$ using a direct 

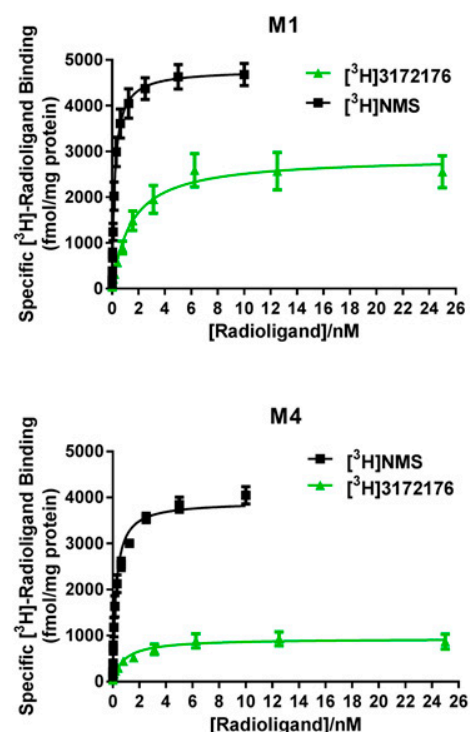
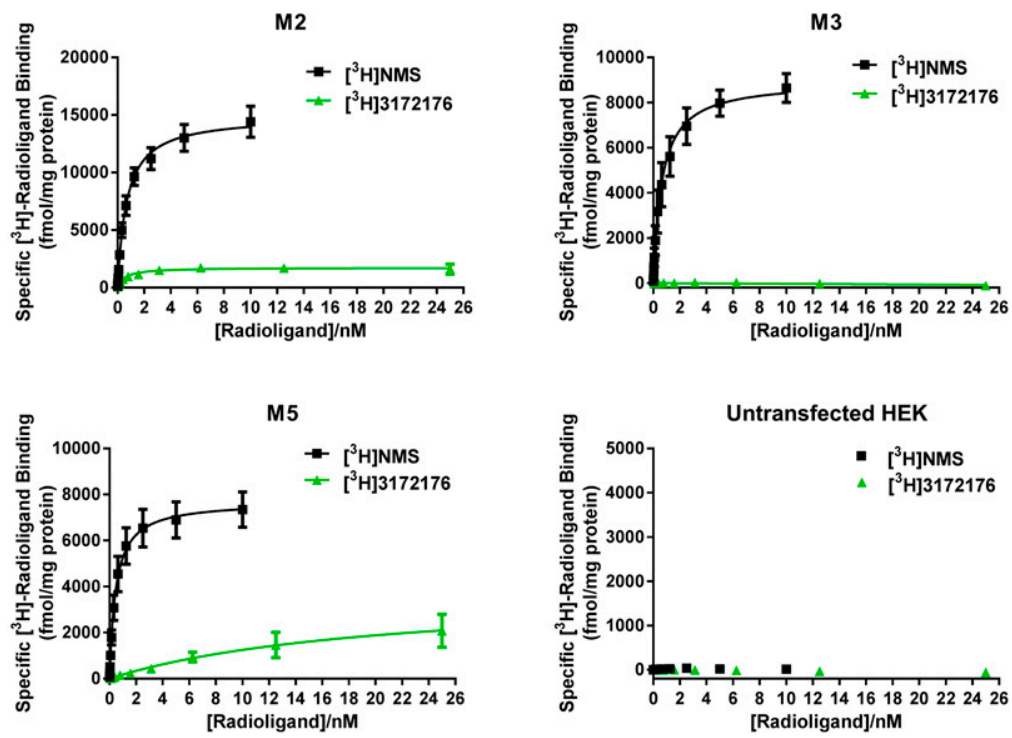

Fig. 6. Saturation binding profile of $\left[{ }^{3} \mathrm{H}\right] \mathrm{LSN} 3172176$. Binding of both $\left[{ }^{3} \mathrm{H}\right] \mathrm{NMS}$ and $\left[{ }^{3} \mathrm{H}\right] \mathrm{LSN} 3172176$ was assessed across human M1-M5 recombinant membranes. For both ligands specific binding was calculated by subtracting the mean nonspecific binding in the presence of $10 \mu \mathrm{M}$ atropine from the mean total binding at each radioligand concentration performed in quadruplicate and then expressed as femtomole $\left[{ }^{3} \mathrm{H}\right]$ ligand binding per milligram protein. Data points represent mean \pm S.E.M. from three independent experiments. HEK, human embryonic kidney cells.

binding assay. This enabled the rapid determination of total and nonspecific binding levels for compounds in membranes containing recombinant human M1 mAChR without the expensive and time-consuming requirement to radiolabel compound. LSN3172176 (structure shown in Fig. 1A) was selected on the basis of its favorable signal (total binding)-tonoise (nonspecific binding) of 21 (Fig. 1B), in comparison with other known PET tracer molecules (5 and 7 for MDL100907 and MK4232, respectively; Table 1). Using the same assay, saturation binding was performed with LSN3172176 generating a $\mathrm{K}_{\mathrm{d}}$ value of $1.5 \mathrm{nM}$ (Fig. 1C). LSN3172176 was then assessed in vitro in a functional GTP $\gamma{ }^{[35]} \mathrm{S}$ binding assay utilizing native tissue from mouse, rat, and human cortex (Fig. 2). In all three species LSN3172176 was a potent, partial agonist, with $\mathrm{EC}_{50}$ values of $7.0,3.7$, and $2.4 \mathrm{nM}$ in mouse, rat, and human, respectively. Efficacy values ranged from $43 \%$ to $73 \%$. No responses were observed in cortical membranes from M1 mAChR knockout mice. Two previous mAChR PET tracer agonist ligands, Xanomeline and GSK1034702 were also assessed in this assay and displayed significantly lower potencies of between 13-17 and 160-425 $\mathrm{nM}$, respectively, with both displaying partial agonist profiles. Efficacy values ranged from $19 \%-45 \%$ to $45 \%-82 \%$ for xanomeline and GSK1034702, respectively.

To further characterize the selectivity of LSN3172176, radioligand competition binding assays were performed using the nonselective muscarinic antagonist $\left[{ }^{3} \mathrm{H}\right] \mathrm{NMS}$ and recombinant membranes from cells expressing human M1-M5 mAChR subtypes (Fig. 3). Results from these assays clearly demonstrated that LSN3172176 exhibited a selectivity profile favoring binding to the M1 subtype of mAChR with a rank order of $\mathrm{K}_{\mathrm{i}}$ values of M1 > M2, M4, M5 > M3. This rank order of potency across mAChRs was similar to the results for GSK1034702; however, GSK1034702 displayed a $\mathrm{K}_{\mathrm{i}}$ value $\sim 100$-fold less potent than LSN3172176. In this assay, xanomeline had approximately equal affinity at all subtypes of mAChR (Table 2).

Characterization of $\left[{ }^{3} \mathbf{H}\right]$ LSN3172176. On the basis of the above results, LSN3172176 was tritiated and further experiments performed to characterize the in vitro selectivity and potency of the $\left[{ }^{3} \mathrm{H}\right] \mathrm{LSN} 3172176$ radioligand itself. In the first instance, kinetic association and dissociation assays were performed. $\left[{ }^{3} \mathrm{H}\right] \mathrm{LSN} 3172176$ association reached steady-state after approximately 1 hour, with dissociation kinetics revealing that $\left[{ }^{3} \mathrm{H}\right] \mathrm{LSN} 3172176$ binding was rapidly reversible (Fig. 4). Both association and dissociation kinetic curves were best fitted to biphasic equations. The results of competition assays using membranes from cells expressing the human recombinant M1 mAChR demonstrated that binding of $\left[{ }^{3} \mathrm{H}\right]$ LSN3172176 was fully displaced by known orthosteric mAChR agonists and antagonists (Fig. 5). Full saturation binding with $\left[{ }^{3} \mathrm{H}\right] \mathrm{LSN} 3172176$ was then performed across the

TABLE 3

Summary of in vitro $K_{d}$ and $B_{\max }$ values \pm S.E.M. for $\left[{ }^{3} \mathrm{H}\right] \mathrm{LSN} 3172176$ and $\left[{ }^{3} \mathrm{H}\right] \mathrm{NMS}$ saturation binding to human recombinant M1-M5 mAChRs

\begin{tabular}{llccccc}
\hline & & M1 & M2 & M3 & M4 & M5 \\
\hline$\left[{ }^{3} \mathrm{H}\right]$ LSN3172176 & $\mathrm{K}_{\mathrm{d}} / \mathrm{nM}$ & $1.5 \pm 0.3$ & $0.6 \pm 0.2$ & NSSB & $0.8 \pm 0.2$ & $20.5 \pm 11.4$ \\
& $\mathrm{~B}_{\max }$ & $2877 \pm 175$ & $1737 \pm 127$ & NSSB & $936 \pm 61.4$ & $3813 \pm 1199$ \\
$\left.{ }^{3} \mathrm{H}\right] \mathrm{NMS}$ & $\mathrm{K}_{\mathrm{d}} / \mathrm{nM}$ & $0.209 \pm 0.025$ & $0.682 \pm 0.093$ & $0.642 \pm 0.121$ & $0.242 \pm 0.026$ & $0.464 \pm 0.093$ \\
& $\mathrm{~B}_{\max }$ & $4786 \pm 128$ & $14916 \pm 568$ & $8959 \pm 466$ & $3909 \pm 97.5$ & $7700 \pm 400$ \\
\% of NMS & & 60 & 12 & N/A & 24 & 50
\end{tabular}

NSSB, no significant saturable binding. 

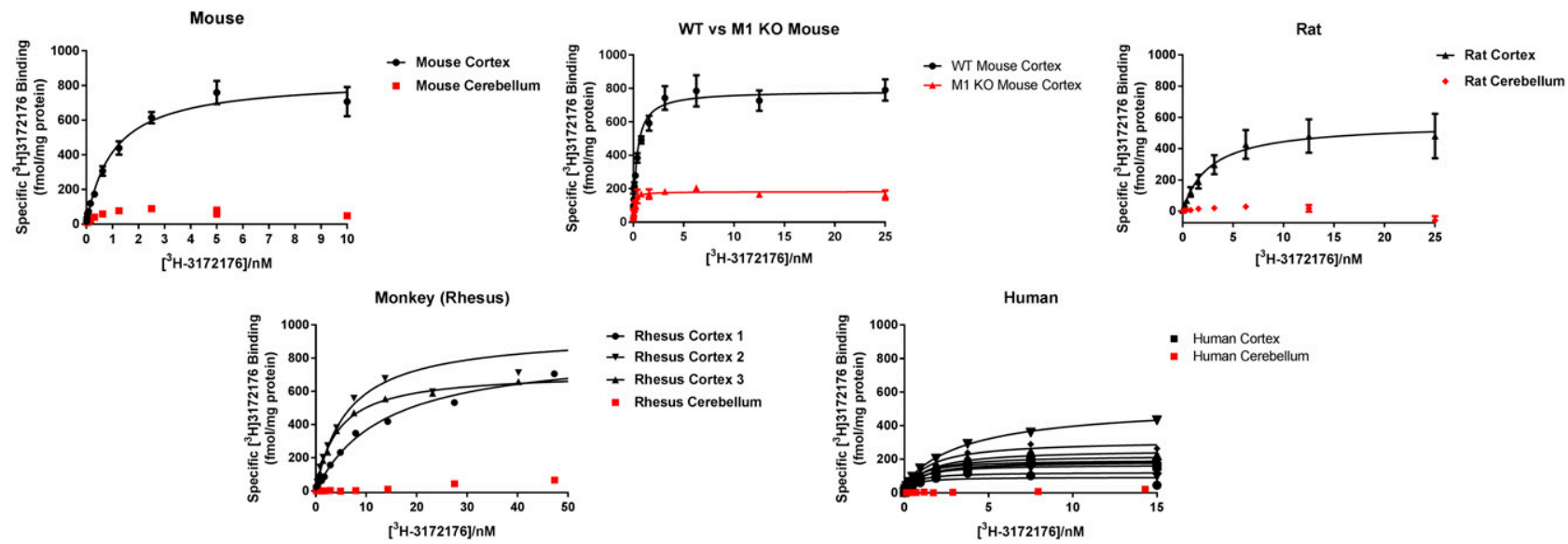

Fig. 7. Native tissue saturation binding. Saturation binding experiments using $\left[{ }^{3} \mathrm{H}\right] \mathrm{LSN} 3172176$ were conducted using brain membranes (frontal cortex and cerebellum) prepared from wild-type and M1 mAChR KO mouse, rat, rhesus monkey, and human. Specific binding was calculated by subtracting the mean nonspecific binding in the presence of $10 \mu \mathrm{M}$ atropine from the mean total binding at each radioligand concentration performed in quadruplicate and then expressed as femtomole $\left[{ }^{3} \mathrm{H}\right] 3172176$ binding per milligram protein. Data points represent mean \pm S.E.M. from three independent experiments.

five different mAChR subtypes (Fig. 6). [ $\left.{ }^{3} \mathrm{H}\right] \mathrm{NMS}$ saturation binding was performed in parallel, to allow a ratio to be made between the total pool of $\mathrm{mAChR}$ binding sites present in the membranes and available for antagonist binding, including activated and uncoupled inactive receptors $\left(\left[{ }^{3} \mathrm{H}\right] \mathrm{NMS} \mathrm{B}_{\max }\right)$ versus the smaller pool of active receptors that is the probable target of $\left[{ }^{3} \mathrm{H}\right] \mathrm{LSN} 3172176$ binding $\left(\left[{ }^{3} \mathrm{H}\right] 3172176 \mathrm{~B}_{\max }\right)$ at steady-state. Although only modest differences were observed in $\mathrm{K}_{\mathrm{d}}$ values between $\mathrm{M} 1, \mathrm{M} 2$, and $\mathrm{M} 4 \mathrm{mAChRs}$, more substantial variations in $\mathrm{B}_{\max }$ values for $\left[{ }^{3} \mathrm{H}\right] \mathrm{LSN} 3172176$ relative to $\left[{ }^{3} \mathrm{H}\right] \mathrm{NMS}$ were noted, with the highest proportion of total binding observed for $\left[{ }^{3} \mathrm{H}\right] \mathrm{LSN} 3172176 /\left[{ }^{3} \mathrm{H}\right] \mathrm{NMS}$ being $\mathrm{M} 1>>\mathrm{M} 4>\mathrm{M} 2>\mathrm{M} 5>\mathrm{M} 3$, respectively (Table 3).

$\left[{ }^{3}\right.$ H]LSN3172176 Binds with High Affinity to Native Tissues. An important aspect of tracer development is to confirm affinity across species in relevant native tissues. Therefore, saturation binding experiments were performed to assess binding of $\left[{ }^{3} \mathrm{H}\right] \mathrm{LSN} 3172176$ using cortical and cerebellar membranes from mouse, rat, rhesus monkey, and human (Fig. 7). In cortical membranes, $K_{d}$ values for $\left[{ }^{3} \mathrm{H}\right]$ LSN3172176 ranged from 1 to $8 \mathrm{nM}$, with some variability in $B_{\max }$ across species (Table 4). The highest $B_{\max }$ values were obtained in monkey cortical tissue and across species; little specific binding was observed to cerebellar tissue. In cortical tissue from M1 mAChR knockout mice, $\mathrm{B}_{\max }$ levels were reduced by $77 \%$; however, some residual specific binding was observed. Binding to human cortical tissue was assessed across 10 separate donors, and whereas $K_{d}$ values were consistent across individual samples, $\mathrm{B}_{\max }$ values varied considerably (Table 4).

Regional Visualization of $\left[^{3} \mathrm{H}\right] \mathrm{LSN3172176}$ Binding in the Brain by Autoradiography. The binding of $\left[{ }^{3} \mathrm{H}\right]$ LSN3172176 was also examined by autoradiography (Fig. 8). Brain slices from wild-type and M1 or M4 mAChR knockout mice were used. Overall, high levels of binding were observed in cortical, hippocampal, and striatal regions, with binding in the hippocampal and cortical areas greatly reduced in the M1 knockout mouse but, interestingly, some residual binding remained in the striatum (Fig. 8A). Similar to results obtained with homogenates, very little binding was seen in cerebellar regions. In slices from M4 mAChR KO mice, levels of binding were only significantly reduced in the striatum. When quantified, the levels of binding that remained were comparable to those seen in homogenate binding assays (Fig. 8B) with virtually all binding displaced by the nonselective $\mathrm{mAChR}$ antagonist atropine.

In Vivo Tracer Distribution and Occupancy Results. Finally, the binding of LSN3172176 to M1 receptors in vivo was evaluated in mice and rats by LC-MS/MS using a cold tracer protocol for specific binding assessment (Chernet et al., 2005). Tracer distribution, after intravenous dosing, was assessed in plasma and in brain regions known to possess high M1 mAChR levels, frontal cortex and striatum, and in cerebellum, a region low in M1 mAChRs used as a null-region. The pattern of LSN3172176 distribution that was observed, high in cortex and striatum, low in cerebellum (Fig. 9A), was consistent with known regional densities. Further work was conducted in rats to explore the utility of LSN3172176 for receptor occupancy studies. For these studies, scopolamine, a ligand shown to compete with LSN3172176 in vitro binding to the M1 orthosteric site, was administered intravenously in escalating doses $(0.01,0.03,0.06,0.1,0.3 \mathrm{mg} / \mathrm{kg}) 30$ minutes

\section{TABLE 4}

Summary of native tissue $\mathrm{K}_{\mathrm{d}}$ and $\mathrm{B}_{\max }$ values for $\left[{ }^{3} \mathrm{H}\right] \mathrm{LSN} 3172176$ binding across species and brain regions

Mean $K_{d}$ and $B_{\max }$ values +/- S.E.M. were calculated from data presented in Fig. 7.

\begin{tabular}{lcc}
\hline \multirow{2}{*}{ Tissue } & \multicolumn{2}{c}{${ }^{3} \mathrm{H}-\mathrm{LSN} 3172176$ Binding to Native Tissues } \\
\cline { 2 - 3 } & $\mathrm{K}_{\mathrm{d}} \pm$ S.E.M. & $\mathrm{B}_{\max } \pm$ S.E.M. Protein \\
\hline Mouse cortex & $n M$ & $\mathrm{fmol} / \mathrm{mg}$ protein \\
Mouse cerebellum & $1.02 \pm 0.15$ & $839 \pm 37$ \\
M1 KO mouse & $\mathrm{NSSB}$ & $\mathrm{NSSB}$ \\
Rat cortex & $0.1 \pm 0.02$ & $182 \pm 6.5$ \\
Rat cerebellum & $2.66 \pm 0.89$ & $562 \pm 58$ \\
Rhesus cortex & $\mathrm{NSSB}$ & $\mathrm{NSSB}$ \\
Rhesus cerebellum & $8 \pm 3$ & $843 \pm 69$ \\
Human cortex & $\mathrm{NSSB}$ & $\mathrm{NSSB}$ \\
Human cerebellum & $1.03 \pm 0.16$ & $224 \pm 35$ \\
& $\mathrm{NSSB}$ & $\mathrm{NSSB}$
\end{tabular}

NSSB, no significant saturable binding. 
A

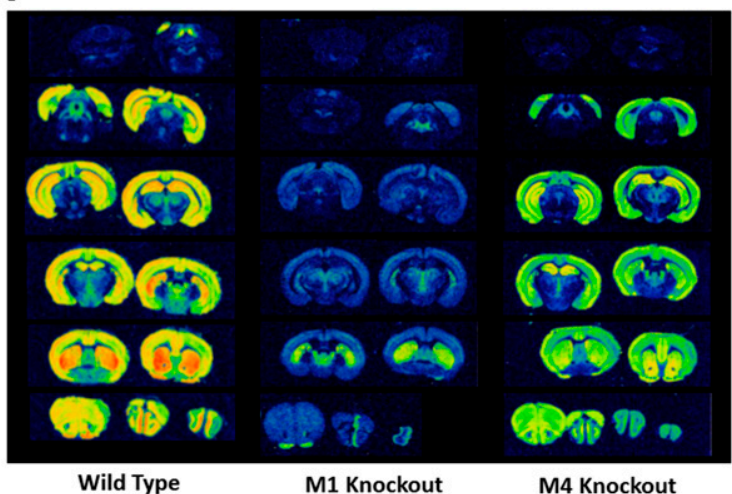

B

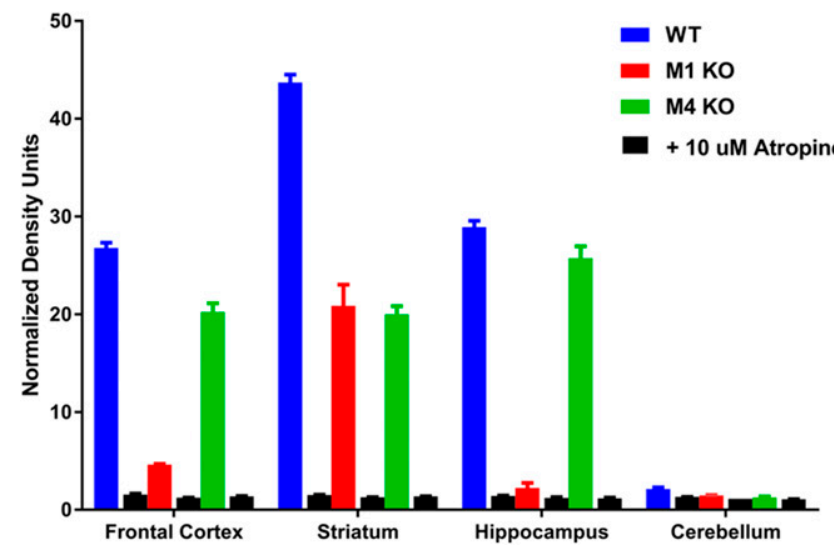

Fig. 8. Autoradiography with $\left[{ }^{3} \mathrm{H}\right] \mathrm{LSN} 3172176$ in the mouse brain. (A) Binding of $\left[{ }^{3} \mathrm{H}\right] \mathrm{LSN} 3172176$ was compared across serial fresh-frozen slices $(20 \mu \mathrm{m})$ from wild-type or M1 or M4 KO mice. A final concentration of $5 \mathrm{nM}$ $\left[{ }^{3} \mathrm{H}\right] \mathrm{LSN} 3172176$ was used for all experiments. Representative images from a single brain are shown below. (B) Quantification of regional $\left[{ }^{3} \mathrm{H}\right]$ LSN3172176 binding was performed using brains from three separate mice from each strain. Bars reflect the average intensity of all pixels in a region of interest and represent the mean \pm S.E.M. for each condition.

prior to tracer (LSN3172176) injection (Fig. 9B). The data shows that scopolamine dose dependently reduced tracer binding in frontal cortex, with near maximal occupancy of the M1 mAChR achieved at $0.3 \mathrm{mg} / \mathrm{kg}$ scopolamine. Additional studies were conducted to verify binding selectivity using wild-type and M1-M5 mAChR KO mice (Fig. 9C). In M1 mAChR KO mice dosed only with the tracer LSN3172176, the binding potential (the ratio of total binding in frontal cortex to nonspecific binding in cerebellum) was reduced from 7.1 to 1.0 relative to the control group of C57BLK6 mice (Fig. 9D). Binding potential values obtained from M2-M5 mAChR KO mice remained unchanged as detected by LC-MS/MS. No changes in tracer levels were observed in the total or nonspecific tissues collected. These data suggest that, in vivo, the specific binding seen in mouse frontal cortex is predominantly the result of binding to M1 mAChR. In striatum, a higher degree of residual occupancy was observed in M1 KO mice, which may correspond to a small amount of binding to M4 and possibly also M2 mAChRs, mirroring the results obtained in the autoradiography experiments (Fig. 8A). Nevertheless, the majority of binding in this region is to the $\mathrm{M} 1$ receptor.

\section{Discussion}

In this study, we have characterized the in vitro and in vivo properties of LSN3172176, a novel M1 mAChR agonist tracer. In vitro, LSN3172176 is a potent, partial, orthosteric agonist at recombinant and native $\mathrm{M} 1 \mathrm{mAChRs}$ and this profile is conserved across species. In in vitro autoradiography and in vivo cold tracer distribution studies, LSN3172176 displays a regional distribution that corresponds closely to the known regional densities of $\mathrm{M} 1 \mathrm{mAChRs}$, and predominant binding to M1 was confirmed using knockout mice. In receptor occupancy studies, LSN3172176 tracer binding was fully displaceable in the presence of a competing, orthosteric, mAChR ligand. On aggregate, this data confirms that LSN3172176 binds to the M1 mAChR in the rodent brain in vivo and that it is suitable for studies of M1 mAChR occupancy. One of the hurdles in the selection and development of successful radiolabeled tracer molecules is the difficultly in predicting the levels of nonspecific and total binding for a given tracer. Radiolabeling all molecules within a defined structure-activity relationship is not only timeconsuming but also extremely expensive. By employing the direct-binding technique described in this study, we were able to rapidly obtain a preliminary assessment of the in vitro binding properties for a number of possible tracer molecules and to benchmark signal-to-noise ratios and $B_{\max }$ levels to those of known PET tracer ligands (Table 1). We theorized that the higher the ratio the more optimal would be the tracer ligand predicted in vitro/in vivo. To our knowledge, use of this technique in this paradigm has not previously been described, but we believe it has the potential to rapidly advance generation of potential PET tracer molecules for further preclinical evaluation.

However, obtaining a good level of signal-to-noise in vitro is only one part of the PET ligand development challenge. Historically, selectivity over the other subtypes of mAChR has been notoriously difficult to obtain owing to the highly conserved nature of the orthosteric binding site across all subtypes of muscarinic receptor (Wess et al., 2007; Ma et al., 2009). Although, LSN3172176 certainly binds to the orthosteric site both in vitro, as demonstrated by $\left[{ }^{3} \mathrm{H}\right] \mathrm{NMS}$ displacement experiments, and in vivo through displacement by scopolamine, we believe that LSN3172176 partially extends into the allosteric binding site (unpublished data), thus providing a possible mechanism to explain its apparent selectivity over the other subtypes of mAChR. This bitopic binding motif conferring improved M1 selectivity has been previously described and is probably a feature of many GPCR ligands (Watt et al., 2011; Lane et al., 2013; Keov et al., 2014). Compared with xanomeline, LSN3172176 showed a superior selectivity for M1 mAChRs in $\left[{ }^{3} \mathrm{H}\right] \mathrm{NMS}$ competition binding studies; however, the $\mathrm{K}_{\mathrm{d}}$ for $\left[{ }^{3} \mathrm{H}\right] \mathrm{LSN} 3172176$ at M1,2 and $4 \mathrm{mAChRs}$ was overlapping, begging the question of why this ligand can still achieve the high degree of in vitro and in vivo selectivity for M1 mAChRs observed in the current study. As we have demonstrated through functional GTP $\gamma^{[35]} \mathrm{S}$ binding in a variety of native tissues, LSN3172176 is a partial agonist across species and would be expected to stabilize the high affinity form of the M1 receptor. This is consistent with our findings that NMS labeled more sites relative to LSN3172176 when assessed in the same recombinant M1-5 membrane preparations. Interestingly, we found that the amount of 


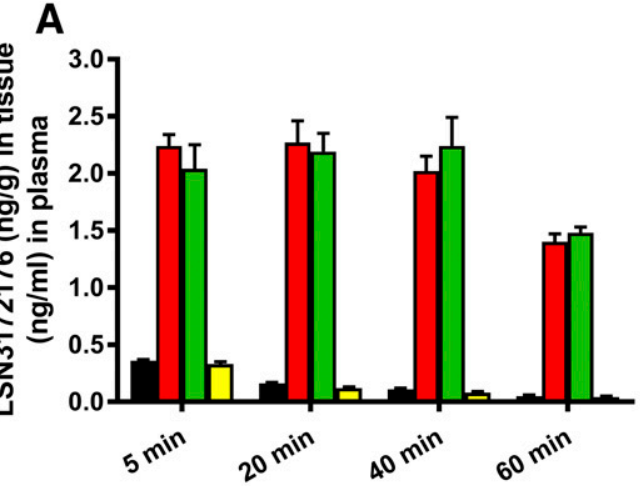

Survival Interval

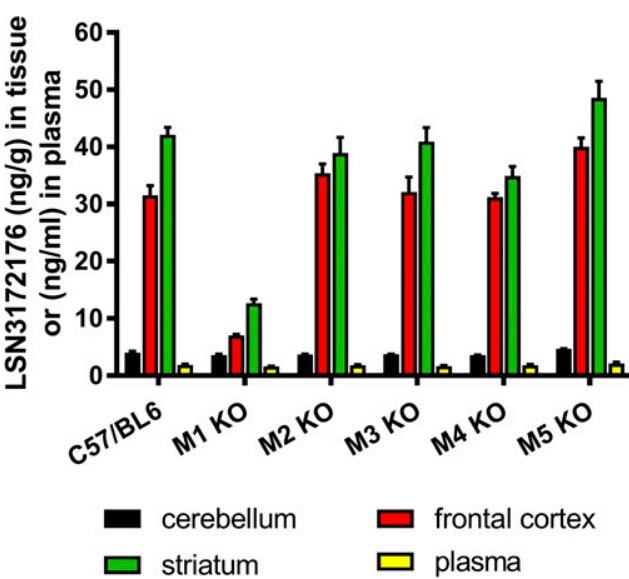

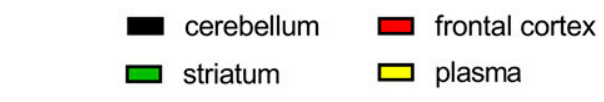

C $\square$ plasma
B

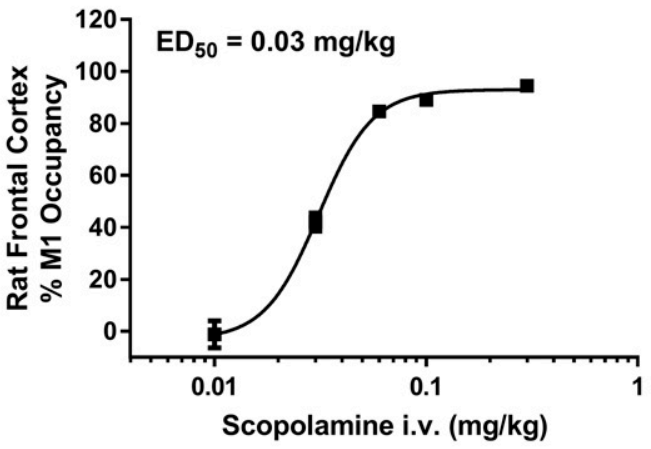

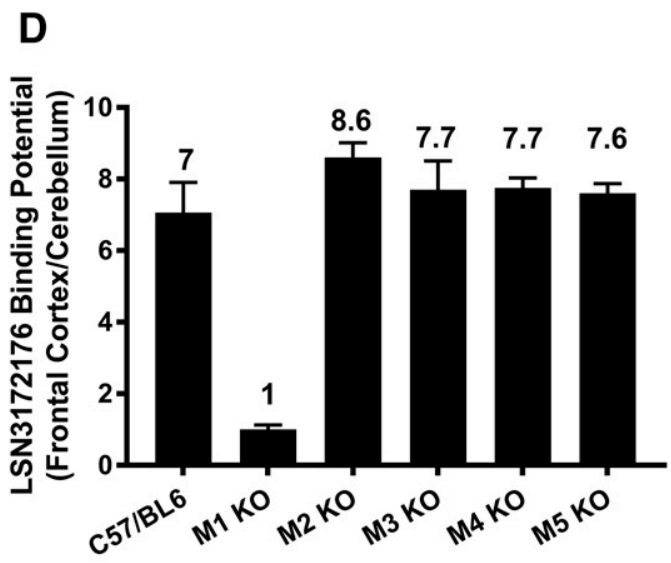

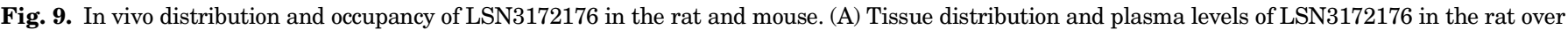

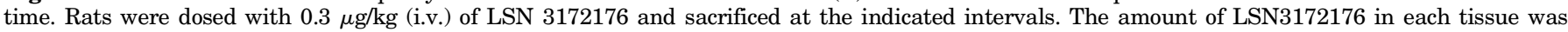

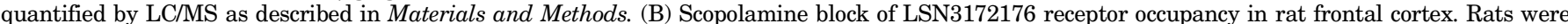

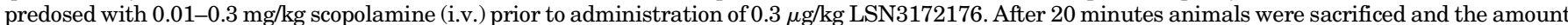

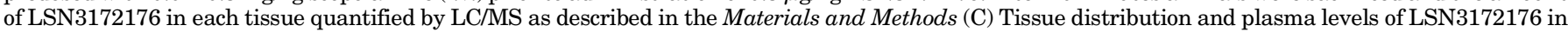

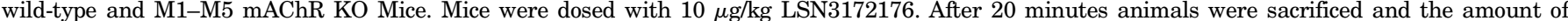

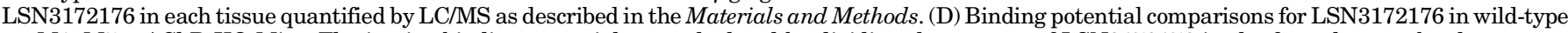

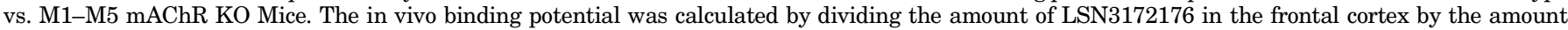
determined in the cerebellum by LC/MS. Bars/points represent mean \pm S.E.M. from $n=3-5$ male mice or rats per treatment group.

maximal binding of the tritiated form of LSN3172176 varied widely relative to NMS binding ( $B_{\max }$ values) across the five mAChR subtypes, and was proportionally highest at the M1 $\mathrm{mAChR}$. Although extrapolation from an overexpressing cell line to native tissues is a potential confound, we believe that this phenomenon, combined with the selectivity displayed in the $\left[{ }^{3} \mathrm{H}\right] \mathrm{NMS}$ competition binding assays and the dominant expression of M1 mAChRs in the brain regions we studied (Supplementary Fig. 1), together probably confer the in vitro and in vivo selectivity of binding at the M1 mAChR.

With a view to clinical translation, another important aspect to confirm during development of a PET tracer molecule was high tracer affinity across species. Using relevant native tissues (cortex, cerebellum) from rodent, monkey, and human tissue, we demonstrated that LSN3172176 retained its affinity for the M1 receptor across species, with regional receptor distributions also shown to be conserved. The variability in total binding observed across individual human samples could be the result of differences within regions, variable expression levels between individuals, or possibly may reflect technical challenges of obtaining consistent quality of postmortem samples. If these levels are correct, albeit lower in human compared with other species, the M1 $\mathrm{B}_{\max }$ levels in human tissue are still higher than the $B_{\max }$ levels of the CGRP or $5-\mathrm{HT}_{2 \mathrm{~A}}$ receptors, the targets of the two other clinically validated PET tracers examined; hence, we do not envisage this will be an issue for PET imaging studies in man (Table 1). In the in vitro autoradiographic and in vivo tracer distribution studies, there also appeared to be a low level of LSN3172176 binding to non-M1 receptors, which was more prevalent in the striatum, a region known to contain a high density of M4 mAChR (Bymaster et al., 2003; Supplemental Fig. 1). As LSN3172176 has high affinity for M4 receptors, in all likelihood these data are the result of binding of the ligand not only to M1 but also to the M4 subtype of mAChR. A modest contribution from binding to $\mathrm{M} 2 \mathrm{mAChR}$ might also be 
plausible given the high affinity LSN3172176 displays for the mAChR subtype as well. If this tracer moves forward as a PET tracer for dose selection for selective M1 agonists, it would be important to focus not just on the region giving the highest binding (which is generally striatum from preclinical studies), but also on the regions where preclinical work suggests the signal is most dominantly contributed by M1 mAChRs (hippocampus, cortex), and where the signal is probably more completely displaceable. Overall, however, the data package supports the binding predominance of LSN3172176 M1 mAChRs across the brain regions studied. Indeed, the binding of LSN3172176 in cortex in vivo was reduced by $\sim 85 \%$ in $\mathrm{M} 1 \mathrm{mAChR} \mathrm{KO}$ mice. Coupled with its retention of affinity in human native tissue we believe that this selectivity should translate favorably to humans. A preliminary report detailing successful carbon labeling and evaluation of $\left[{ }^{11} \mathrm{C}\right] \mathrm{LSN} 3172176$ as a PET tracer in nonhuman primates revealed $\left[{ }^{11} \mathrm{C}\right] \mathrm{LSN} 3172176$ possessed high brain uptake, appropriate tissue kinetics, and high specific binding (Nabulsi et al., 2017). As in our studies, scopolamine pretreatment reduced radiotracer binding, with 98.5\% target occupancy achieved at $50 \mu \mathrm{g} / \mathrm{kg}$, i.v. Moreover, the $\mathrm{ED}_{50}$ dose (30 $\mu \mathrm{g} / \mathrm{kg}$ i.v). of scopolamine reversal obtained in the current study is highly relevant as this dose range is associated with disruption of attention and sensory discrimination (Klinkenberg and Blokland, 2010). From these preliminary reports, $\left[{ }^{11} \mathrm{C}\right] \mathrm{LSN} 3172176$ appears to be superior to previously reported muscarinic PET ligands. For example, in comparison with $\left[{ }^{11} \mathrm{C}\right] \mathrm{AF} 150(\mathrm{~S})$ (Buiter et al., 2013), LSN3172176 is more potent and displays a considerably higher binding potential in vivo in rats.

There are very few GPCR-agonist clinical PET ligands, with the notable exception of $\left[{ }^{11} \mathrm{C}\right]$ carfentanil. This agonist PET ligand has been used extensively to evaluate the role of the $\mu$-opioid receptor in health and disease and to detect occupancy changes in response to changes in endogenous tone or administered $\mu$-opioid drugs (Frost et al., 1985; van Waarde et al., 2014). Dopamine D2 receptor agonist PET ligands have also been reported (e.g., Otsuka et al., 2009). If the nonhuman primate PET studies with $\left[{ }^{11} \mathrm{C}\right] \mathrm{LSN} 3172176$ successfully translate to man, this molecule should prove to be a highly valuable tool to aid dose setting for M1 ligands and for evaluation of M1 mAChRs in human health and disease.

\section{Acknowledgments}

Human tissue samples were from Randy Woltjer at the Oregon Alzheimer's Disease Center.

\section{Authorship Contributions}

Participated in research design: Mogg, Gehlert, Jesudason, M.P. Johnson, Felder, Barth, Broad.

Conducted experiments: Mogg, Eessalu, M. Johnson, Wright, Sanger,

Xiao, Schober, Crabtree, Smith, Colvin.

Contributed new reagents or analytic tools: Goldsmith.

Performed data analysis: Mogg, Eessalu, M. Johnson, Sanger, Wright, Barth.

Wrote or contributed to the writing of the manuscript: Mogg, Felder, Barth, Broad.

\section{References}

Anagnostaras SG, Murphy GG, Hamilton SE, Mitchell SL, Rahnama NP, Nathanson NM, and Silva AJ (2003) Selective cognitive dysfunction in acetylcholine M1 muscarinic receptor mutant mice. Nat Neurosci 6:51-58.

Bakker G, Vingerhoets WA, van Wieringen J-P, de Bruin K, Eersels J, de Jong J, Chahid Y, Rutten BP, DuBois S, Watson M, et al. (2015) 123I-iododexetimide preferentially binds to the muscarinic receptor subtype M1 in vivo. J Nucl Med $\mathbf{5 6}$ 317-322.

Ballinger EC, Ananth M, Talmage DA, and Role LW (2016) Basal forebrain cholinergic circuits and signaling in cognition and cognitive decline. Neuron 91: $1199-1218$

Betterton RT, Broad LM, Tsaneva-Atanasova K, and Mellor JR (2017) Acetylcholine modulates gamma frequency oscillations in the hippocampus by activation of muscarinic M1 receptors. Eur J Neurosci 45:1570-1585.

Bodick NC, Offen WW, Levey AI, Cutler NR, Gauthier SG, Satlin A, Shannon HE, Tollefson GD, Rasmussen K, Bymaster FP, et al. (1997) Effects of xanomeline, a selective muscarinic receptor agonist, on cognitive function and behavioral symptoms in Alzheimer disease. Arch Neurol 54:465-473.

Bohnen NI, Kaufer DI, Hendrickson R, Ivanco LS, Lopresti BJ, Koeppe RA, Meltzer CC, Constantine G, Davis JG, Mathis CA, et al. (2005) Degree of inhibition of cortical acetylcholinesterase activity and cognitive effects by donepezil treatment in Alzheimer's disease. $J$ Neurol Neurosurg Psychiatry 76:315-319.

Boundy KL, Barnden LR, Rowe CC, Reid M, Kassiou M, Katsifis AG, and Lambrecht RM (1995) Human dosimetry and biodistribution of iodine-123-iododexetimide: a SPECT imaging agent for cholinergic muscarinic neuroreceptors. J Nucl Med 36: 1332-1338.

Bradley SJ, Bourgognon J-M, Sanger HE, Verity N, Mogg AJ, White DJ, Butcher AJ, Moreno JA, Molloy C, Macedo-Hatch T, et al. (2017) M1 muscarinic allosteric modulators slow prion neurodegeneration and restore memory loss. J Clin Invest 127:487-499.

Buiter HJ, Windhorst AD, Huisman MC, Yaqub M, Knol DL, Fisher A, Lammertsma AA, and Leysen JE (2013) [11C]AF150(S), an agonist PET ligand for M1 muscarinic acetylcholine receptors. EJNMMI Res 3:19.

Butcher AJ, Bradley SJ, Prihandoko R, Brooke SM, Mogg A, Bourgognon J-M, Macedo-Hatch T, Edwards JM, Bottrill AR, Challiss RAJ, et al. (2016) An antibody biosensor establishes the activation of the M1 muscarinic acetylcholine receptor during learning and memory. J Biol Chem 291:8862-8875.

Bymaster FP, McKinzie DL, Felder CC, and Wess J (2003) Use of M1-M5 muscarinic receptor knockout mice as novel tools to delineate the physiological roles of the muscarinic cholinergic system. Neurochem Res 28:437-442.

Cheng Y and Prusoff WH (1973) Relationship between the inhibition constant (K1) and the concentration of inhibitor which causes 50 per cent inhibition (I50) of an enzymatic reaction. Biochem Pharmacol 22:3099-3108.

Chernet E, Martin LJ, Li D, Need AB, Barth VN, Rash KS, and Phebus LA (2005) Use of LC/MS to assess brain tracer distribution in preclinical, in vivo receptor occupancy studies: dopamine D2, serotonin $2 \mathrm{~A}$ and NK-1 receptors as examples. Life Sci 78:340-346.

Cummings JL, Geldmacher D, Farlow M, Sabbagh M, Christensen D, and Betz P (2013) High-dose donepezil ( $23 \mathrm{mg} /$ day) for the treatment of moderate and severe Alzheimer's disease: drug profile and clinical guidelines. CNS Neurosci Ther 19: 294-301.

DeLapp NW, McKinzie JH, Sawyer BD, Vandergriff A, Falcone J, McClure D, and Felder CC (1999) Determination of $\left[{ }^{35}\right.$ S]guanosine-5'-O-(3-thio)triphosphate binding mediated by cholinergic muscarinic receptors in membranes from Chinese hamster ovary cells and rat striatum using an anti-G protein scintillation proximity assay. J Pharmacol Exp Ther 289:946-955.

Dennis SH, Pasqui F, Colvin EM, Sanger H, Mogg AJ, Felder CC, Broad LM, Fitzjohn SM, Isaac JTR, and Mellor JR (2016) Activation of muscarinic M1 acetylcholine receptors induces long-term potentiation in the hippocampus. Cereb Cortex 26 414-426.

Dewey SL, MacGregor RR, Brodie JD, Bendriem B, King PT, Volkow ND, Schlyer DJ, Fowler JS, Wolf AP, Gatley SJ, et al. (1990) Mapping muscarinic receptors in human and baboon brain using $\left[\mathrm{N}^{11} \mathrm{C}-\mathrm{methyl}\right]$-benztropine. Synapse 5:213-223.

Douchamps V and Mathis C (2017) A second wind for the cholinergic system in Alzheimer's therapy. Behav Pharmacol 28:112-123.

Farde L, Suhara T, Halldin C, Nybäck H, Nakashima Y, Swahn CG, Karlsson P, Ginovart N, Bymaster FP, Shannon HE, et al. (1996) PET study of the M1-agonists $\left[{ }^{11} \mathrm{C}\right]$ xanomeline and $\left[{ }^{11} \mathrm{C}\right]$ butylthio-TZTP in monkey and man. Dementia 7 187-195.

Felder CC, Goldsmith PJ, Jackson K, Sanger HE, Evans DA, Mogg AJ, and Broad LM (2018) Current status of muscarinic M1 and M4 receptors as drug targets for neurodegenerative diseases. J Neuropharmacol DOI: 10.1016/j.neuropharm.2018.01.028 [published ahead of print].

Flynn DD, Ferrari-DiLeo G, Mash DC, and Levey AI (1995) Differential regulation of molecular subtypes of muscarinic receptors in Alzheimer's disease. $J$ Neurochem 64:1888-1891.

Frost JJ, Wagner HN, Jr, Dannals RF, Ravert HT, Links JM, Wilson AA, Burns HD, Wong DF, McPherson RW, Rosenbaum AE, et al. (1985) Imaging opiate receptors in the human brain by positron tomography. J Comput Assist Tomogr 9:231-236.

Hasselmo ME and Sarter M (2011) Modes and models of forebrain cholinergic neuromodulation of cognition. Neuropsychopharmacology 36:52-73.

Hostetler ED, Joshi AD, Sanabria-Bohórquez S, Fan H, Zeng Z, Purcell M, Gantert L Riffel K, Williams M, O'Malley S, et al. (2013) In vivo quantification of calcitonin gene-related peptide receptor occupancy by telcagepant in rhesus monkey and human brain using the positron emission tomography tracer $\left[{ }^{11} \mathrm{C}\right] \mathrm{MK}-4232 . J$ Pharmacol Exp Ther 347:478-486.

Jesudason C, Barth V, Goldsmith P, Ruley K, Johnson M, Mogg A, Colvin E, Dubois S, Broad L, Felder C, et al. (2017) Discovery of two novel, selective agonist radioligands as PET imaging agents for the M1 muscarinic acetylcholine receptor. $J$ Nucl Med 58:546.

Keov P, López L, Devine SM, Valant C, Lane JR, Scammells PJ, Sexton PM, and Christopoulos A (2014) Molecular mechanisms of bitopic ligand engagement with the M1 muscarinic acetylcholine receptor. J Biol Chem 289:23817-23837.

Klinkenberg I and Blokland A (2010) The validity of scopolamine as a pharmacological model for cognitive impairment: A review of animal behavioral studies. Neurosci Biobehav Rev 34:1307-1350. 
Kuhl DE, Minoshima S, Frey KA, Foster NL, Kilbourn MR, and Koeppe RA (2000) Limited donepezil inhibition of acetylcholinesterase measured with positron emission tomography in living Alzheimer cerebral cortex. Ann Neurol 48:391-395

Lane JR, Sexton PM, and Christopoulos A (2013) Bridging the gap: bitopic ligands of G-protein-coupled receptors. Trends Pharmacol Sci 34:59-66.

Lange HS, Cannon CE, Drott JT, Kuduk SD, and Uslaner JM (2015) The M1 muscarinic positive allosteric modulator $\mathrm{PQCA}$ improves performance on translatable tests of memory and attention in Rhesus monkeys. J Pharmacol Exp Ther 355: $442-450$.

Laruelle M, Abi-Dargham A, Casanova MF, Toti R, Weinberger DR, and Kleinman JE (1993) Selective abnormalities of prefrontal serotonergic receptors in schizophrenia. A postmortem study. Arch Gen Psychiatry 50:810-818.

Lavalaye J, Booij J, Linszen DH, Reneman L, and van Royen EA (2001) Higher occupancy of muscarinic receptors by olanzapine than risperidone in patients with schizophrenia. A[123I]-IDEX SPECT study. Psychopharmacology (Berl) 156:53-57.

Levey AI, Kitt CA, Simonds WF, Price DL, and Brann MR (1991) Identification and localization of muscarinic acetylcholine receptor proteins in brain with subtypespecific antibodies. $J$ Neurosci 11:3218-3226.

Ma L, Seager MA, Wittmann M, Jacobson M, Bickel D, Burno M, Jones K, Graufelds VK, Xu G, Pearson M, et al. (2009) Selective activation of the M1 muscarinic acetylcholine receptor achieved by allosteric potentiation [published correction appears in Proc Natl Acad Sci USA (2009) 106:18040]. Proc Natl Acad Sci USA 106:15950-15955.

Mcpherson DW (2001) Targeting cerebral muscarinic acetylcholine receptors with radioligands for diagnostic nuclear medicine studies, in Ion Channel Localization: Methods and Protocols (Lopatin AN and Nichols CG, eds) pp 17-38, Humana Press, Totowa, NJ.

Mohamed A, Eberl S, Fulham MJ, Kassiou M, Zaman A, Henderson D, Beveridge S, Constable C, and Lo SK (2005) Sequential ${ }^{123}$ I-iododexetimide scans in temporal lobe epilepsy: comparison with neuroimaging scans (MR imaging and 18F-FDG PET imaging). Eur J Nucl Med Mol Imaging 32:180-185.

Mulholland GK, Kilbourn MR, Sherman P, Carey JE, Frey KA, Koeppe RA, and Kuhl $\mathrm{DE}$ (1995) Synthesis, in vivo biodistribution and dosimetry of $\left[{ }^{11} \mathrm{C}\right] \mathrm{N}$ methylpiperidyl benzilate $\left(\left[{ }^{11} \mathrm{C}\right] \mathrm{NMPB}\right)$, a muscarinic acetylcholine receptor antagonist. Nucl Med Biol 22:13-17.

Müller-Gärtner HW, Wilson AA, Dannals RF, Wagner HN, Jr, and Frost JJ (1992) Imaging muscarinic cholinergic receptors in human brain in vivo with Spect, [123I]4-iododexetimide, and [123I]4-iodolevetimide. J Cereb Blood Flow Metab 12: $562-570$.

Nabulsi N, Holden D, Zheng M-Q, Slieker L, Barth V, Lin S, Kant N, Jesudason C, Labaree D, Shirali A, et al. (2017) Evaluation of a novel, selective M1 muscarinic acetylcholine receptor ligand ${ }^{11} \mathrm{C}-\mathrm{LSN} 3172176$ in non-human primates. $\mathrm{J} \mathrm{Nucl}$ Med 58:275.

Nathan PJ, Watson J, Lund J, Davies CH, Peters G, Dodds CM, Swirski B, Lawrence P, Bentley GD, O'Neill BV, et al. (2013) The potent M1 receptor allosteric agonist GSK1034702 improves episodic memory in humans in the nicotine abstinence model of cognitive dysfunction. Int $J$ Neuropsychopharmacol 16:721-731.

Oki T, Takagi Y, Inagaki S, Taketo MM, Manabe T, Matsui M, and Yamada S (2005) Quantitative analysis of binding parameters of $\left[{ }^{3} \mathrm{H}\right] \mathrm{N}$-methylscopolamine in central nervous system of muscarinic acetylcholine receptor knockout mice. Brain Res Mol Brain Res 133:6-11.

Otsuka T, Ito $\mathrm{H}$, Halldin $\mathrm{C}$, Takahashi $\mathrm{H}$, Takano $\mathrm{H}$, Arakawa R, Okumura $\mathrm{M}$, Kodaka F, Miyoshi M, Sekine M, et al. (2009) Quantitative PET analysis of the dopamine $\mathrm{D} 2$ receptor agonist radioligand ${ }^{11} \mathrm{C}-(\mathrm{R})-2-\mathrm{CH} 3 \mathrm{O}-\mathrm{N}-\mathrm{n}$-propylnorapomorphine in the human brain. $J$ Nucl Med 50:703-710.

Overk CR, Felder CC, Tu Y, Schober DA, Bales KR, Wuu J, and Mufson EJ (2010) Cortical M1 receptor concentration increases without a concomitant change in function in Alzheimer's disease. J Chem Neuroanat 40:63-70.

Potter DD, Pickles CD, Roberts RC, and Rugg MD (2000) Scopolamine impairs memory performance and reduces frontal but not parietal visual P3 amplitude. Biol Psychol 52:37-52.

Puri V, Wang X, Vardigan JD, Kuduk SD, and Uslaner JM (2015) The selective positive allosteric M1 muscarinic receptor modulator PQCA attenuates learning and memory deficits in the Tg2576 Alzheimer's disease mouse model. Behav Brain Res 287:96-99.

Rasmusson DD and Dudar JD (1979) Effect of scopolamine on maze learning performance in humans. Experientia 35:1069-1070.

Ridler K, Cunningham V, Huiban M, Martarello L, Pampols-Maso S, Passchier J, Gunn RN, Searle G, Abi-Dargham A, Slifstein M, et al. (2014) An evaluation of the brain distribution of $\left[\left({ }^{11)} \mathrm{C}\right] \mathrm{GSK} 1034702\right.$, a muscarinic-1 (M 1) positive allosteric modulator in the living human brain using positron emission tomography. EJNMMI Res 4:66.

Robbins TW, Semple J, Kumar R, Truman MI, Shorter J, Ferraro A, Fox B, McKay G and Matthews K (1997) Effects of scopolamine on delayed-matching-to-sample and paired associates tests of visual memory and learning in human subjects: comparison with diazepam and implications for dementia. Psychopharmacology (Berl) 134:95-106.

Rogers SL and Friedhoff LT; The Donepezil Study Group (1996) The efficacy and safety of donepezil in patients with Alzheimer's disease: results of a US multicentre, randomized, double-blind, placebo-controlled trial. Dementia 7:293-303.

Shirey JK, Brady AE, Jones PJ, Davis AA, Bridges TM, Kennedy JP, Jadhav SB Menon UN, Xiang Z, Watson ML, et al. (2009) A selective allosteric potentiator of the M1 muscarinic acetylcholine receptor increases activity of medial prefrontal cortical neurons and restores impairments in reversal learning. $J$ Neurosci 29: 14271-14286.

Tan C-C, Yu J-T, Wang H-F, Tan M-S, Meng X-F, Wang C, Jiang T, Zhu X-C, and Tan L (2014) Efficacy and safety of donepezil, galantamine, rivastigmine, and memantine for the treatment of Alzheimer's disease: a systematic review and metaanalysis. J Alzheimers Dis 41:615-631.

Teles-Grilo Ruivo LM and Mellor JR (2013) Cholinergic modulation of hippocampal network function. Front Synaptic Neurosci 5:2.

Uslaner JM, Eddins D, Puri V, Cannon CE, Sutcliffe J, Chew CS, Pearson M, Vivian JA, Chang RK, Ray WJ, et al. (2013) The muscarinic M1 receptor positive allosteric modulator PQCA improves cognitive measures in rat, cynomolgus macaque, and rhesus macaque. Psychopharmacology (Berl) 225:21-30.

van Waarde A, Absalom AR, Visser AKD, and Dierckx RAJO(2014) Positron emission tomography (PET) imaging of opioid receptors, in PET and SPECT of Neurobiological Systems (Dierckx RAJO, Otte A, de Vries EFJ, van Waarde A, and Luiten PGM eds) pp 585-623, Springer, Heidelberg, Berlin.

Varastet M, Brouillet E, Chavoix C, Prenant C, Crouzel C, Stulzaft O, Bottlaender M, Cayla J, Mazière B, and Mazière M (1992) In vivo visualization of central muscarinic receptors using $\left[{ }^{11} \mathrm{C}\right]$ quinuclidinyl benzilate and positron emission tomography in baboons. Eur J Pharmacol 213:275-284.

Vardigan JD, Cannon CE, Puri V, Dancho M, Koser A, Wittmann M, Kuduk SD, Renger JJ, and Uslaner JM (2015) Improved cognition without adverse effects: novel M1 muscarinic potentiator compares favorably to donepezil and xanomeline in rhesus monkey. Psychopharmacology (Berl) 232:1859-1866.

Veroff AE, Bodick NC, Offen WW, Sramek JJ, and Cutler NR (1998) Efficacy of xanomeline in Alzheimer disease: cognitive improvement measured using the computerized neuropsychological test battery (CNTB). Alzheimer Dis Assoc Disord 12:304-312.

Vora MM, Finn RD, Boothe TE, Liskwosky DR, and Potter LT (1983) [N-methyl- $\left.{ }^{11} \mathrm{C}\right]-$ scopolamine: synthesis and distribution in rat brain. J Labelled Comp Radiopharm 20:1229-1236.

Voss T, Li J, Cummings J, Doody R, Farlow M, Assaid C, Froman S, Leibensperger H, Snow-Adami L, McMahon KB, et al. (2016) MK7622, a positive allosteric modulator of the M1 acetylcholine receptor, does not improve symptoms in Alzheimer's disease: a randomized, double-blind, placebo-controlled proof of concept trial. $J$ Prev Alzheimers Dis 3:336-337.

Watt ML, Schober DA, Hitchcock S, Liu B, Chesterfield AK, McKinzie D, and Felder CC (2011) Pharmacological characterization of LY593093, an M1 muscarinic acetylcholine receptor-selective partial orthosteric agonist. J Pharmacol Exp Ther 338:622-632.

Wei J, Walton EA, Milici A, and Buccafusco JJ (1994) m1-m5 muscarinic receptor distribution in rat CNS by RT-PCR and HPLC. $J$ Neurochem 63:815-821.

Wess J, Eglen RM, and Gautam D (2007) Muscarinic acetylcholine receptors: mutant mice provide new insights for drug development. Nat Rev Drug Discov 6:721-733.

Wilson AA, Dannals RF, Ravert HT, Frost JJ, and Wagner HNJ, Jr (1989) Synthesis and biological evaluation of $\left[{ }^{125} \mathrm{I}\right]-$ and $\left[{ }^{123} \mathrm{I}\right]$-4-iododexetimide, a potent muscarinic cholinergic receptor antagonist. J Med Chem 32:1057-1062.

Zhang L and Villalobos A (2017) Strategies to facilitate the discovery of novel CNS PET ligands. EJNMMI Radiopharm Chem 1:13.

Zubieta JK, Koeppe RA, Frey KA, Kilbourn MR, Mangner TJ, Foster NL, and Kuhl $\mathrm{DE}$ (2001) Assessment of muscarinic receptor concentrations in aging and Alzheimer disease with $\left[{ }^{11} \mathrm{C}\right] \mathrm{NMPB}$ and PET. Synapse 39:275-287.

Address correspondence to: Dr. Adrian J. Mogg, Eli Lilly and Company Ltd, Erl Wood Manor, Windlesham GU20 6PH, Surrey, UK. E-mail: mogg_adrian@lilly.com 